University of Rhode Island

DigitalCommons@URI

Open Access Master's Theses

1976

\title{
Land Banking as a Redevelopment Tool for the City of Providence
}

Joseph J. Seymour

University of Rhode Island

Follow this and additional works at: https://digitalcommons.uri.edu/theses

\section{Recommended Citation}

Seymour, Joseph J., "Land Banking as a Redevelopment Tool for the City of Providence" (1976). Open Access Master's Theses. Paper 743.

https://digitalcommons.uri.edu/theses/743

This Thesis is brought to you for free and open access by DigitalCommons@URI. It has been accepted for inclusion in Open Access Master's Theses by an authorized administrator of DigitalCommons@URI. For more information, please contact digitalcommons-group@uri.edu. 
LAND BANKING AS A

REDEVELOPMENT TOOL FOR THE

CITY OF PROV IDENCE

MASTERS RESEARCH PROJEC'P. GRADUATE CURRICULUM IN COMMUNITY PLANNING AND AREA DEVELOPMENT

By 'Joseph J. Seymour University of Rhode Island December, 1976. 
MASTERS RESEARCH PROJECT

GRADUATE CURRICULUM IN COMMUNITY PLANNING

AND AREA DEVELOPMENT

UNIVERSITY OF RHODE ISLAND

Candidate, Joseph J. Seymour

Degree Sought: Masters in Community Planning

Title of Tool for the City of Providence

Approved by:

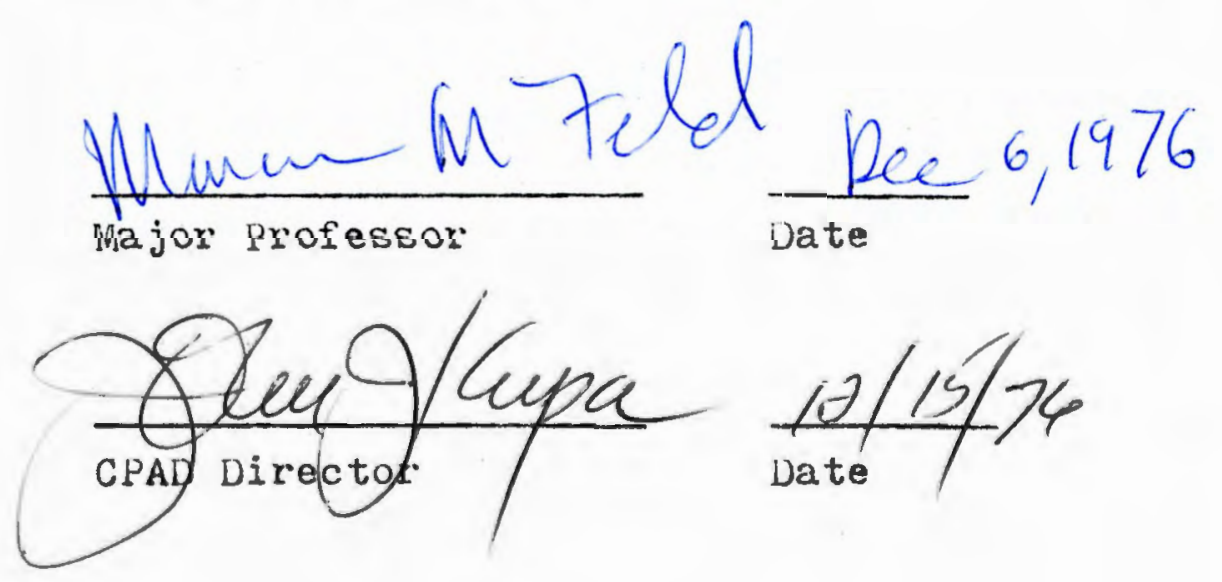


TABLE OF CONTEN'IS

Chapter

Page

INTRODUCTION

I THE IAND BANKING CONCEPT. . . . . . . . . 1

II LAND BANKING IN PROVIDENCE . . . . . . . 10

III THE LEGAL BASIS FOR LAND BANKING • • • • 29

IV IMPLEMENTATION . . . . . . . . . . . 44

Sec. 1 Proposal Goals and objectives. . 44

Sec. 2 Operational rramework . . . . . 47

Sec. 3 Acquisition Strategies...... 48

Sec. 4 site selection ........ 60

Sec. 5 pinancing ... ........ 63

Sec. 6 Land Management .. . . . . . 67

Sec. 7 Disposition of Land . . . . . 68

CONCLUSION . . . . . . . . . . . 72

BIBLIOGRAPHY . . . . . . . . . 76

APPENDIX I St. Louis Land Banking Law

APPENDIX II roreclosure Legislation for Homesteading

APPENDIX III Private Redevelopment Legislation 


\section{TABLES}

TABLE NUMBER

I

II

III

IV

V
TITLE

PAGE

Population Trend . . . . 11

Delinguent 'lax

l'rend . . . . . . 18

Recent Demolition

By City Plat..... 20

City owned Land in or

Adjacent to Disinvested

Areas that is not in Public

use in $1975 . . .449$

Unsold Urban Renewal

Iand as of Oct. 13, 1976. 50 


\section{MAPS}

MAP NUMBER

Map One

Map Two

Map Three

Map Four
TITLE

Map of Uninvested and Disinvested Areas

City Iand not in Public Use and Unsold Urban Renewa $\perp$ Land by Plat

Concentration of Tax Reverted Iand in city by Plat

Vacant Land in Providence 1971
IOCATION

Pg. $16 \mathrm{~A}$

Insert I. Insert 2

Pg. $56 \mathrm{~A}$ 


\section{AC KNOW LEDGEMENTS}

The research for this report required the cooperation and assistance of many department heads and employees of the City of Providence. Their time and efforts are greatly appreciated. I am especially grateful to chief of Planning. Martha Bailey, and her staff at the Department of Planning and Urban Development. Also graditude is given for the interest and assistance from; City Clerk vincent vespia, Collector of Taxes kon Tarro, City Assessor Ted Littler, Mayor's Assistant Bob Vincent, and Community Development Coordinator Torrez Kelly.

I am deeply indebted to my professors who gave direction to the preparation of this report. Appreciation is acknowledged to Dr. Richard Brooks who provided legal review and guidance. Many thanks to Dr. Marcia field for her guidance, editorial expertize and encouragement. Finally, special thanks to my wife, Susan for her typing, editing, encouragement and domestic patience. 
The purpose of this report is to explore the potential of a land banking program for the City of Providence, Khode Island. This analysis hopefully will provide City authorities with a better understanding of the land banking concept. It may also provide a base upon which the City can decide whether it should pursue a land bank program.

Providence like many of our older cities is faced with economic and social problems resulting from changes in American living preferences. New highways, increases in family income, and other factors have resulted in the migration of thousands to surrounding city suburbs. This has left only the poor in many of the older neighborhoods. Since the poor were unable to afford home ownership or pay for maintenance, slums and blighted neighborhoods evolved in some areas. Houses were abandoned and demolished, and in some cases, urban renewal was utilized in an attempt to revitalize the area. Where urban renewal failed, vacant land was left which only added to the blight and continued decline.

In contrast, land is becoming scarce in some suburbs as development reaches the metropolitan fringes. A continued demand for land and the uncertain future of inner city areas raises questions of what policies and programs should be applied to our deteriorated inner city areas. One of the proposals advanced has been to create city land banks. 
The Providence Department of Planning and Urban Development has indicated an interest in a land banking program as a mechanism to deal with City owned land not in public use, and as an aid for future city revitalization. However, land banking is not a common practice in the United States. As a revitalization tool it is a recent concept.

The lack of empirical evidence, for land banking dictates that before the city could undertake such a program, an analysis of land banking must be made. Hopefully this report can give the city some insight and direction.

Chapter I will explore the concept of land banking. A review of its history, in foreign countries and the United States and its potential application to the inner city will be discussed. Chapter II looks at the general real estate and investment trends in the city and focuses on the concept of disinvestment. An analysis of legal issues that are raised by a city land bank are discussed in Chapter III. In Chapter IV, goals and objectives that could be achieved through a land banking program are proposed. Strategies and procedures required by the city to carry out a land banking program wi11 then be explored and analyzed. 


\section{THE LAND BANKING CONCEPT}

Land banking is a broad concept. It cover's a variety of both public asd private activities that can be directed toward a multitude of goals. Public land banking. for purposes of classification, can be grouped into two broad catagories-general land banking or special purpose land banking. 1 A comprehensive definition of general land banking in terms of purpose, scale and method is as follows: The acquisition by a public body of developed and undeveloped land, holding of land, and disposition of land, for all types of land uses-public and private-without prior specification of the use for particular sites. The deliberate purposes of the acquisition ares control of the metropolitan growtn pattern and/or regulation of metropolitan land prices and/or regulation of land use. In short, general land banking would be a program that would change the nature of the private market.

The most common form of general land banking is a regiona $\perp$ land bank.

The definitions that follow, draw upon those given by Harvey Flechner in. Iand Banking in the Control of Urban Development. (Praeger Pub, New York, 1974), and Herbert Franklin in. In Zoning (Potomac Institute, washington, D.C. 1974). p. 180 .

2 Regional land banking has been advocated as a tool to control urban spraw $\perp$ and thereby achieve cost savings to government, industry and private citizens. Proponents argue that by acquisition of large open space at the urban fringe. land would be available for future regional growth and the pattern of development could be determined by government plan and policy. Land banking on a regional or metropolitan Level would also curtail land speculation which is in effect a tax on citizens as consumers. For example, by witholding land from the market, speculators create a shortage and in effect, drive up the price of land and then sell for a profit. These practices have in effect eliminated the savings we have achieved in construction technology. The net result is 
However, creation of a regional land bank in the United States is questionable from both a financial and legal standpoint. 3

Special purpose land banking is distinguished from general land banking in that 1 t is concerned with a specific project or functional area. In general. characteristics that distinguish it from general land banking are as follows, It is limited geographically to smaller areas; limited to individual juristictions: and Iimited in size of land holdings. In essence, it involves public participation in the market for the public purpose rather than attempting to change the nature of the private market.

In this report, we are specifically concerned with banking land in blighted areas of the central city,

higher priced homes which fewer families can afford. Public land banking could keep land prices stable by releasing an orderly flow of land for private redevelopment as needed. In effect, public land banking would let government bring about development it seeks rather than having to use regulations to prevent the worst.

3William L. Letwin, in Municipal Land Banks, Land Reserve Policy for Urban Development (Urban Land Research Analysis Corp., Lexington, Mass. 1969), has estimated that for a land bank to be effective in the Boston area. would require an expenditure of $\$ 250 \mathrm{million}$. Also for a land bank to assemble land properly, requires the power of condemnation. Franklin, (op cit pg 189) states, "The existing lines of judicial opinion in allowing condemnation for the public purpose would have to be dependent upon the existence of some publicly approved development plan.... Those strategies that suggest land banking acquisition beyond the urbanizing fringe might well be infeasible because of the difficulty of producing the kind of plan that might legally be required". However, special purpose land banks, having a more narrowly defined public purpose, would appear to be able to meet a Court reviow, a discussion of legal issues that relate to apecial purpose land banking is provided.in Chapter 3. 
either for, specific future redevelopments such as recreation, housing or industry, or for public holding until the city's economic and investment conditions improve. This concept is classified as special purpose land banking.

Further application of inner city land banking will be discussed later in this chapter. However, to gain a better understanding of land banking the experiences of foreign countries and the United states will be reviewed.

Foreign Experience:

Land banking in European countries is a common practice. It has probably been most successful in Sweden. A program instituted in Stockholm in 1904 has resulted in one-half of the present city boundaries now being occupied on land that was banked. 4 The advantages have included; financial savings from advanced acquisition, a decrease in speculation, attainment of the master plan, and public profit from land sold or leased to prïvate developers.

Great Britain's experience in land banking has primarily been new town development, which the united Stated paralleled in the "New Community Program" under the 1970 Urban Growth and Community Development Act. The major difference between these programs was that the British government provided financing, while the American program had only loan guarantees. 
The Canadian Provinces of Alberta and Saskatchewan initiated a municipal land bank program through acquisition of substantial amounts of tax delinquent land during the Depression. Subsequently, land development and growth policies were adopted with the land banking mechanism serving as the implementing tool.

other land banking programs have been identified in Germany, Israel. Hong Kong, Australia, Finland, Denmark and Norway, and the Netherlands. 5 In the Netherlands, Amsterdam acquires and leases all land except industrial sites which are sold. Rotterdam leases industrial sites. Both programs are successful in shaping urban growth patterns. 6

of particular interest to the United States from a legal perspective is the Puerto Rico land bank program. It was undertaken to meet the enormous land speculation occurring in conjunction with rapid growth. Speculators had caused fragmented and unmanageable growth by holding scattered parcels as San Juan expanded. A Land banking administration was empowered with the use of eminent domain and bonding powers to purchase land and sell it for development that was in the public interest. As of June 1970, the Administration had acquired almost 24,000 acres. This has allowed the construction of thousands of low and moderate income housing due to the reduction of land cost

5For further detail see Parsons et al Public Land Acquisition for $\mathrm{New}$ Communities and the Control of Urban Growth: Alternative Strategies. (Cornell University Center for Urban Development Research, Ithaca, N.Y.) 1973. 6Reps, John W.. The future of American Planning: Requiem or Renascence:, Land Use Controls. Vol 1, no. 2, 1967. p.7. 
inherent in the economics of large scale acquisition.?

The significant impact of this program has been its survival

in the Puerto Rico and United States Supreme Courts. 8.

\section{United States Experience,}

Such large scale land banking programs as exist in other countries are not found in the United States. This is due in part, to the fragmentation of government in our metropolitan areas, and our economic system that allows the private market to determine land use and value. These factors present obstacles to land assembly on a scale necessary to create a large land bank. However, the failure of the market to provide for efficient and orderly growth and the subsequent social costs resulting from this failure, may indicate that some public intervention should be made in the market place. Aside from proponents cited in this report there are a number of Commissions and organizations that have advocated land banking as a tool for better urban development. 9

Recently small special purpose land banks appear to be gaining in application. A few of these programs are worth brief mention.

7Fishman, Richard P., "Note Public Land Banking: A New Praxis for Urban Growth.: Case Western Reserve Law Review, 1972. p. 922 .

8 Commonwealth v. Rosso ---P.R.---1967 specifically provided for land reserve as a means of promoting the efficient utilization of land. In an appeal to the U.S. Supreme Court, Rosso v. Puerto Rico 393 U.S. 14(1968), the Court granted the Commonwealth's motion to dismiss the appeal on the grounds that the case failed to present a substantial federal question.

9A sampling of those advocating land banking have been: the Douglas Commission, Kaiser Committee. Advisory Committee on Intergovernmental Relations, National Committee of Urban Growth Policy Housing and Urban Development Act of 1970 - 
Fairfax County, Virginia, adopted a land banking program in July 1974. The Board of Supervisors set aside \$2 miliion of County revenue sharing funds, for land banking which will be the cornerstone of a planning and Land Use System to manage growth. The priorities of the program are for community development with particular attention for lowmoderate income housing sites. 10

In Philadelphia, the Philadelphia Development Corporation ( $P H D C$ ) has used land banking as a tool in inner city revitalization. BHDC is a non-profit corporation established by the City, whose objective is to expand the supply of decent housing for low-moderate income families. In addition to land banking. PHDC's tools are rehabilitation, public improvements, and neighborhood improvement groups. Their funding is supplied through conventional federal sources and a $\$ 2$ million city appropriation for a revolving fund. In the land banking program. PHDC acquires vacant Lots, derelict buildings, tax delinquent properties and other properties that contribute to neighborhood decay. The properties are then sold to public or private redevelopers for new construction or rehabilitation. While not a large scale program, it has shown the value of land banking for parcel assembly and cutting red tape. of significance to this study is the st. Louis land banking experience. Geared for inner city revitalization,

and the Internation Confederation of Free Trade Unions. For more detail see Sylvan Kamm - Land Banking: Public Policy Alternatives and Dilemmas, (The Urban Institute) 1970. loSee Mary Elizabeth Holbern "Land Banking, Saving For A Rainy Day." Planning, Jan. 1975. 
given by Lawrence Cox, Norfolk Redevelopment and Housing Authority Director, according to him:

"Delays and Land lying idle are inevitable if urban renewal is going to do what it should downtown. Projects involving great investment do not spring full blown upon the scene in the average American community. Delay counseled by realistic appraisal of land potential is a worthwhile delay." 13

Aside from assisting ailing urban renewal projects, inner city land banking could certainly be used in its own right as a land assembly agency. Donald E. Priest, Director, Research Division of the Urban Land Institute has mare such a proposal. He feels that central city land banking deserves serious study by professional and public policy makers. The concept provides a tool for land assembly in areas where the market has ceased to operate. Assuming that through sound public policy, city decay wi $\perp$ cease and a renascence will begin, a municipal land reserve policy that deliberately acquires, and holds land can be an enormous asset for future growth and optimum development. Similarly, Charles Haar sees land banking as a tool for perfecting the land market. "Assembling pockets of blight in to economic plots and making them available in a planned pattern would impart more order to the whole process of urban growth and uncertainty would be reduced." 14 pg. 933.

13Address to ASPO 1960. Cited in Fishman op. cit..

14Haar, Charles "Wanted: Two Federal Levers for Urban Use, - Land Bank and Urbank." (A paper presented at a hearing before the House Banking committee on "Housing production, Housing Demand and Developing a Suitable Environment") June 1971. P. 935. 
it has shown itself to be a valuable tool for redevelopment planning, particularly in recycling decayed urban land. The program, initiated in 1971, has in two years acquired more than 5000 parcels of tax delinquent land and disposed of $10 \%$ for industry and housing. Considering the nature and objectives of this program, it could serve as a useful mode $\perp$ for the city of Providence. A review of this program will be discussed in chapter 2 .

While these three examples are by no means exhaustive, they represent the experience of land banking in the United States 11 , that is to say, on a small scale and in the developing stages.

Application to inner city:

Land banking for the inner city where decay and disinvestment are prevalant is a recent concept. Already familar to blighted city areas is the application of urban renewal, which, to many has not entirely met up to its expectations. In the opinion of one expert; "The requirements of programming the completion of renewal projects within five to eight years of the final planning often results in hurried, wasteful, piecemeal and often extravagant development inimical to the city's future." 12 In contrast, land banking could provide a mechanism to supplement the time and money urban renewal lacked. Iand banking could also provide a needed delay when optimum development was not eminent. Support for this concept is

11There are industrial land banks in Baltimore, Philadelphia and Milwaukee, Dade County, Florida; Montgomery County, Maryland, and Greensboro, N.C. have used land banking for low income housing sites.

12Brownfield as quoted in Fishman op. cit., pg 933. 
In summary, the concept of land banking has a broad application. In the United States, it appears that a land bank for a special purpose such as inner city land banking, presents a better chance of implementation when one considers our history and system of government. To pursue this possibility for the City of Providence, this report will investigate certain characteristics of the City to establish whether the need for such a tool exists. 


\section{Iand Banking In Providence}

Historical Perspective:

Providence is the capital city and the industrial and cultural center of Rhode Island. Founded in 1636 and incorporated in 1832, it has become a major commercial, financial and industrial center in New England. However, like many other older Eastern cities it has stabilized and begun to decline. At the turn of the 19th century, Providence gradually changed its economic base from shipping to manufacturing. Drawing on a good port for raw materials and an abundance of water and labor, textile manufacturing became the chief industry. After the Civil War, the City expanded its industrial base to highly diversified industries such as paint, jewelry, and sewing machines. Just after the Civil War, Providence ranked tenth amoung cities in the United States in volume of business. Such growth brought opportunity and the city became the home of many immigrants. In $1875.49 \%$ of the state's population was foreign born. In 1890, the City's population was 132,000 . With a diversifled industrial base and annexation of surrounding land, providence continued to grow. By 1900 , the population was 175.597 and in 1910 it was $224,326$.

After world war I, the City begun to stabilize its growth. Competition in textiles from the South, development of subdivisions within the city boundaries, and rail transportation to the suburbs were among the major reasons. 
By 1920 , the City was growing at the same rate as the State as a whole.

Following World war II, the City began to show signs of decline, This is evidenced by the City's loss of population which continues today. (See Table I.)

\section{TABLE I}

POPULATION TREND

$\begin{array}{lll}\frac{\text { YEAR }}{1950} & \text { POPULATION } & \text { CHANGE } \\ 1960 & 207,700 & \\ 1970 & 179,100 & (-) 41,200 \\ 1975 & 168,100 & (-) 11,000\end{array}$

Source: U.S.
office. 1970, 1975 .

Between 1950-1960 the City's loss in population was concentrated in married households. Such a loss exacerbates future population and economic decline as future family formation opportunities are lost to the city. The majority of the families that did move from the city were from higher income and higher status areas. Low income families moved from downtown to the peripheral areas in the City, thus occupying the structures other families left behind. The reasons which underlie the City's population decline are interrelated and include:

(a) Loss of jobs: In 1950, 162,100 were employed in the City. By 1960, this figure was at 139,000 . 
In contrast, jobs in the rest of the state increased from 173,000 to 190,000 in the same period.

(b) A rise in income: as income of city residents rose, new opportunities were opened.

(c) Changes in transportation technology: New interstate highways cut travel time to the central business district freeing employees to settle further from the city.

(d) Federal housing programs: programs such as F.H.A. mortgage guarantees assistance, encourage city residents to settle in new homes in low density areas. This new lifestyle was welcomed in contrast to higher density City environments in which $85 \%$ of the housing stock was built prior to 1929.

(3) Public action in highways and urban renewal: Between 1947-62, 1,215 families were relocated due to highways and 1,165 families due to urban renewal. While many of the poor residents from urban renewal were rehoused in housing projects in the city, the great majority of those displaced by highways relocated outside the city.

The evidence of the shift of the City's population to the suburbs can be seen in the data collected in the 1964 Community Renewal Program. While 469 families moved into the City in 1960, 1,278 migrated to the suburbs. 15

The City Today:

Present City characteristics reflect a continuation of the long series of disinvestments that have occurred in Providence. 16 The overall. Economic Development Program dated

15 Sources for the above scenerio were taken from the Community Renewal Program by Blair Associates, Inc.. Planners 1964. Providence Monograph prepared by the R.I. Dept. of Economic Development 1976, Rhode Island Basic Economic statistics Summary and Trends: prepared by the R.I. Dept. of Economic Div. 1975.

160ne does not however, want to obtain the impression that there is no economic vitality left in the city. There still fre areas of industrial expansion and neighborhood stability. The college Hill area has undergone a renascence 
May 1976, prepared by the Rhode Island Statewide Planning Program, shows only a total of $33,000 \mathrm{sq}$. feet of new commercial construction in 1975, the lowest figure since 1966. Also in 1975, there were 17 industrial properties totaling $1,448,000 \mathrm{sq}$. feet for sale, the largest offering of existing buildings in Rhode Island.

The City in recent years has lost major commercial outlets. Recently the President of Textron, the City's single largest corporation has publicly stated that without overall changes in the Providence economic climate his firm would be forced to seek a new location within the next ten years. 17 such dilemmas are those that accompany spiral decline. Loss of population means a loss of support for retailing and services, which leads to a loss of amenities, which in turn means further population loss. Such forces are difficult to arrest and require more than just urban renewal and public housing programs.

and other neighborhoods such as Federal Hill and the East Side have shown signs of stability. Some industrial and commercial developments in the past few years are as follows:

Industrial Expansion

Vargas Mgf. Nortek

Marshall Contractors

Commercial Expansion

Conn. General Life Ins. Co.

Civic Center

R.I. Hospita $\perp$ Trust Nat' $\perp$ Bank

Petro Lane (Propane Tanks)

Algonquin Gas Co.

Marriot Motor Lodge

Source: Prov. Monograph 1976, R.I. Department of Economic Development

Such developments lend support to a theory of government ald and sound public policy as an impetus toward revitalization.

17Economic Development Application, prepared by the Dept. of Planning and Urban Development, 1976.

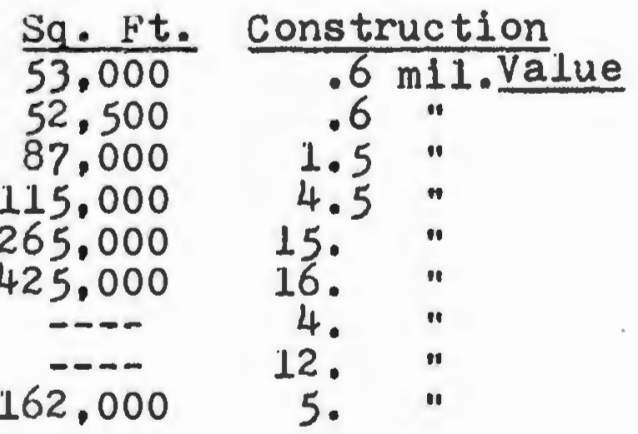


A case in point is upper South providence. In 1964. the CRP had recommended varying degrees of clearance and conservation for the area. Two urban renewal programs were subsequently carried out. However, to date no development has occurred; on the contrary, the area has suffered continued decline to a point that there is no hope for maintaining any sense of the former neighborhoods that once existed in the area. 18

Disinvestment: Impact and Implications

Disinvestment represents a loss of investor confidence in an area to a point that investors take increasingly more money out of the area and put less money back for maintenance. According to George Sternlieb, the prelude to disinvestment is represented by tax delinquency and abandonment. 19

18The Graduate Program in Community Planning at the University of Rhode Is land studied the Upper South Providence area in the spring of 1976. Extensive socio-economic data is contained in the report: Northern South Providence: Policy and Program Recommendations for Community Development. Some significant trends in the neighborhood are:

- A population decrease from 12,767 in 1950 to 1,341 in 1974

- A steady increase in the numbers of poor and minorities

-A 26\% increase in vacant land between 1971-76 (in 1976 there was 30 acres of vacant land that was formerly improved. This represented $40 \%$ of the net land area.)

-A $24 \%$ decrease in the number of structures between 1971-75 mostily due to abandonment and code enforcement.

-An increase in the vacancy rate from $9.4 \%$ in 1960 to $19.4 \%$ in 1970 .

- A decline in housing values from 1960-70. 19Sternlieb, George, "Abandoned Housing: What is to be done?" Urban Land VoI 31, no. 3, March 1972. 
Tax delinquency shows the beginning of investor and ownership decline in the area, and abandonment the complete detatchment. The reasons for abandonment is more complex than the popular notion of laying the blame on the City slum lord. Sternlieb states: "A strong thesis can be made that much of the problems of the low income private housing stock in the central core stem from the disappearance of the large scale slum lord who, if nothing more, at least had the professional and technical capacity to maintain the units." 20 Sternlieb's investigations of the abandonment process, attributes the phenomenon to:

-the elderly in the central city who cannot afford to maintain their homes.

-the small scale absentee landlord, (many who inherited the unit), who have little interest or confidence in the area and rent it strictly to get what money they can.

-ethnic minority owners who cannot afford to maintain the structure, and obtain bank financing; and due to the loss of confidence in the area are unable to realize an increase in home value in relation to rehabilitation costs.

- the combination of the above which results in physical and social decline to a point that the residents cannot wait to leave the area.

These problems are difficult to solve. An initial prerequisite to solve them requires fresh money be pumped into the area along with supporting public policy. However, our cities cannot afford this and financial institutions do not regard this as a pressing need. The problem in effect becomes contagious. Code enforcement and demolition replace a blighting structure with a blighting vacant lot. 
Untimely rehabilitation (the kind that is too late) only increases investor skepticism.

Thus, many of these areas may be beyond rejuvenation. It is possible that after a certain point, public monies only slow down the inevitable decline. In St. Louis a team of consultants studying an economic development strategy recommended that the worst neighborhoods be Left to decline so efforts could be put to saving areas with more potential. 21

Disinvestment in Providence:

The Urban League of Rhode Island, Inc., in a 1973 position paper on disinvestment in central city areas, identified in collaboration with the Rhode Is land Department of Community Affairs and the Providence Department of Planning, areas of disinvestment in the City of Providence. (See Map No. I) The previously mentioned study by the University of khode Is Land clearly documents the amount of disinvestment and abandonment forces in Upper South Providence. If one agrees with Sternlieb's theory of tax deliquency as a prelude to abandonment, the City of providence is and will continue to be faced with a problem of abandoned and vacant land.

The following data has been researched and is

21National Council for Urban Economic Development, Urban Land Recycling and Economic Development Policy in St. Louis. (1620 Eye St. N.W. Washington, D.C.), Nov. 1975. 22Urban League of Rhode Is Land, Disinvestment in Central City Areas, (A position paper). September 1975. 
MAP I

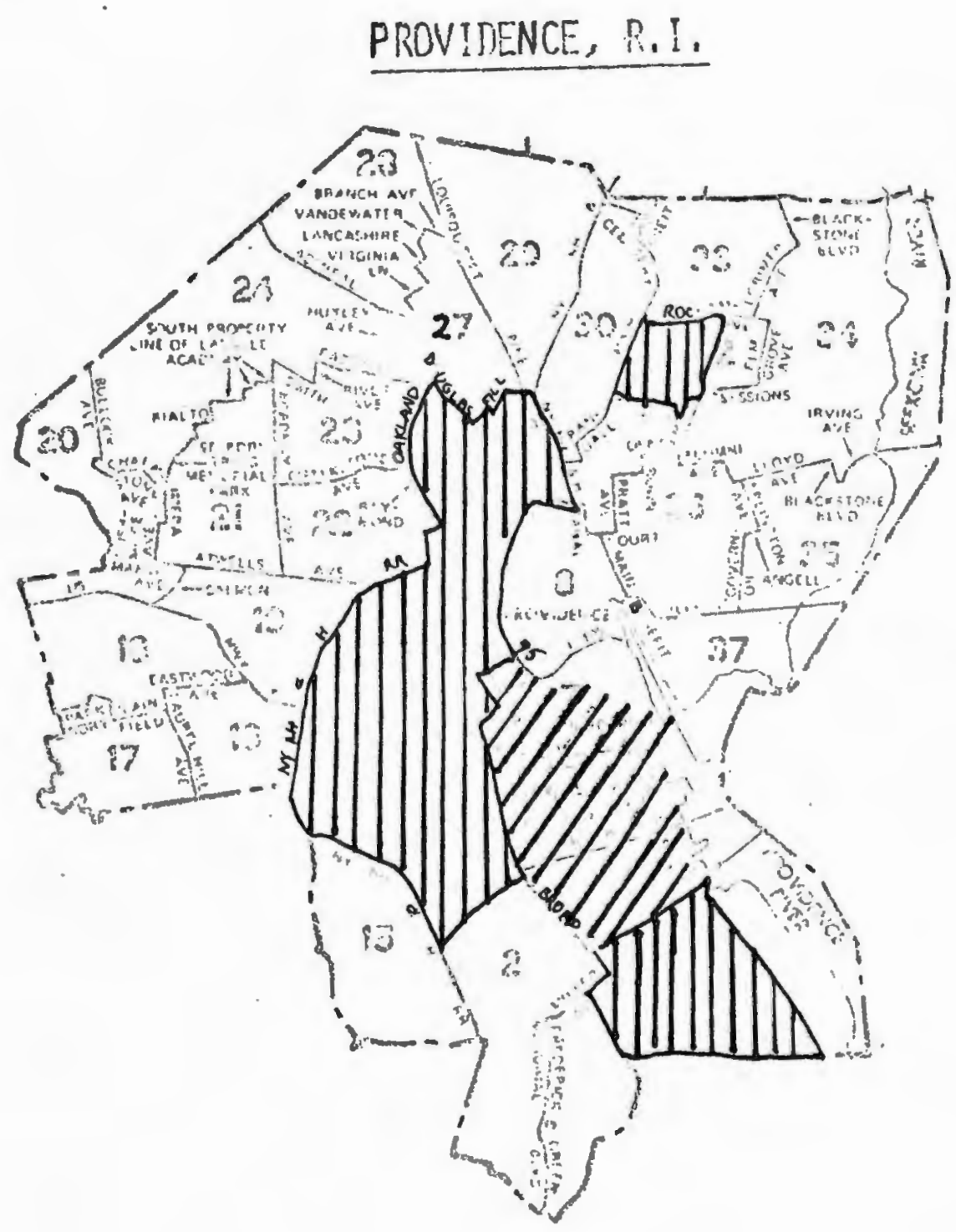

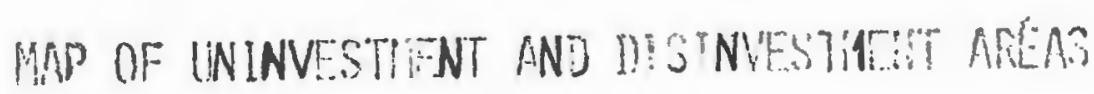

Dis invessant

Uninvestment
Prolirimary ockignations

ociolier 1973

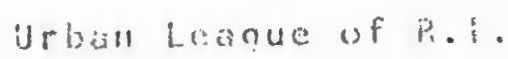


indicative of the extent of disinvestment in Providence.

Tax Delinquency: Table II shows the tax delinquency trend in the city of providence for the five years 1970-74. For an understanding of the implications of this data, comprehension of the city tax collection system is necessary. A summary of the tax collection system of the city is as follows:

City property is assessed at $85 \%$ of the real property value. Taxes are due in JuLy. Should the taxes not be paid by the due date, they are declared delinquent and are subject to a penalty until paid. Unpaid taxes are offered at a tax sale in January of the following year. Prior to the sale, the owner and any mortgagors are notified of the upcoming sale. In most cases the owner or those who have an interest in the property will pay the taxes plus penalty if they feel the property still has an economic value. Should payment not be made, taxes are offered for sale at a tax sale, unless the tax collector feels there is still a chance of collecting the taxes.

Unpaid taxes are usually bought by speculators who pay the back taxes and subsequently continue to pay them in later years. Eventually the speculator will initiate foreclosure proceedings and obtain absolute title to the property. Should there be no purchase of the back taxes the property is reverted to the City (the City buys the back taxes)

23This data has been obtained through research and with the cooperation of the City Clerk, Tax Assessors Office, Tax Collectors office, and City Planning office. 
and the city has tax title.

According to the city tax collector, tax reverted property is usually dead property. 'The owner very rarely redeems the property by paying for the back taxes. 25 Further, the City rarely forecloses on the property to take absolute title since the city has no program or policy for management or disposal of these properties. 26

\section{TABIE II}

\section{DELINQUENT TAX TREND}

Delinquent

Taxes

$1974 \quad 1,610$

19731,475

19721,290

$1971 \quad 1,218$

$1970 \quad 1,280$
$\%$ of City

Parcels

$4 \%$

$3.5 \%$

$2.9 \%$

$2.8 \%$

$2.9 \%$
Subsequentily Paid

$$
1,244
$$

1,233

1,041

1,012

1,020
Sold at Held from Tax Sale lax Sale 19

23

16

19

13
203

122

175

120

162
Revert

to $\mathrm{Cit}$

144

97

58

67

85

The location and delinquent amounts by plat were not readily available. The tax collector is trying to get all tax collection data computerized. This would allow greater analysis of data for a multitude of purposes.

Sources City Tax Collector, 1976.

As Table II indicates tax delinquency in the City is increasing. In 1970, tax payments were not collected on $2.9 \%$ of City parcels. In 1974 tax payments were not collected on

24 For further detail see-Chapter $44 \mathrm{sec} 9-1$ to $9-15$ of the K.I. General Laws

25 In comparing tax reverted property trends on 1 y 10 properties had been removed between 1974-76, while 108 were added.

26Interviews on $9 / 9 / 76$ with the city clerk, Tax collector and Kecorder of Deeds indicated tax foreclosures to be a rarity. Reasons were that the city had no policy for the sale of land, and the foreclosure is a complicated legal process. 
$4 \%$ of the parcels; a $37 \%$ increase. Such a trend reflects a decrease in the vitality of City neighborhoods and business. Property owners are either unable to pay taxes or are abandoning their properties. The end of the disinvestment cycle is reflected by properties sold at the tax sale or reverted to the City.

In 1974 the city bought tax title through reversion on 420 city parcels, this represented $\$ 43.000$ in unpaid taxes. In 1976 this figure had increased to 518 and $\$ 52,386$ respectively. 27 (See Map III. Insert 2 showing concentration of tax reverted land by plat.) while the dollar amounts of unpaid taxes are not great in relation to total City revenues, the figures are understated; many of the properties have been abandoned and subsequently demolished, thus the tax levy is on vacant land. Of the 1974. tax reverted land, $85.5 \%$ was vacant; in $1976.85 \%$ was vacant. 28 Purchase of tax title by speculators also distorts the magnitude of disinvestment, since the majority of these parcels are vacant. Thus, while the city received tax payments from the speculators in subsequent years payment is only for vacant land. This allows the speculator to afford to hold the land in anticipation of future development that will occur most likely through public initiative.

Map IV, Chapter IV, shows vacant land in the City as of 1971 ( 734 acres). 29 This map combined with analysis of

270btained from Research on tax reverted land in the City Tax Assessors office.

28 Ibid.

29Source: Department of Planning and Urban Development 
areas having a concentration of tax reverted land, (Map III), and the map prepared by the Urban League, clearly gives a strong indication of the areas of disinvestment in the city. However, such data is already obsolete, Disinvestment once entrenched, works fast as witnessed by the continued demolition of structures.

Table III lists City plats where the greatest demolition occurred in the years 1973-1976. The great majority of the demolition was the result of urban renewal and code enforcement, both other indicators of disinvestment.

\section{TABLE III}

\section{RECENT DEMOLITION BY CITY PLAT}

\begin{tabular}{lrrrrrrrrrr} 
PLAT & 23 & 28 & 29 & 30 & 31 & 32 & 33 & 35 & 37 & 43 \\
\hline Year- & & & & & & & & & & \\
1973 & 35 & 9 & 3 & 10 & 7 & 5 & 3 & 1 & 1 & 9 \\
1974 & 14 & 4 & 8 & 8 & 7 & 11 & 3 & 3 & 2 & 11 \\
1975 & 19 & 9 & 8 & 8 & 7 & 4 & 3 & 3 & 2 & 6 \\
$1976 *$ & 9 & - & 3 & 3 & 3 & 2 & 3 & $\underline{8}$ & 6 & 2 \\
to May & 14.1976 & & & & & & & & & \\
TOTAL- & 104 & 22 & 16 & 29 & 24 & 22 & 12 & 15 & 11 & 28
\end{tabular}

\begin{tabular}{|c|c|c|c|c|c|c|c|c|c|c|}
\hline PLAT & 44 & 45 & 46 & 47 & 48 & 49 & 53 & 54 & 57 & 68 \\
\hline $\begin{array}{l}\text { Year- } \\
1973 \\
1974 \\
1975 \\
1976 *\end{array}$ & $\begin{array}{r}11 \\
9 \\
9\end{array}$ & $\begin{array}{r}26 \\
27 \\
18 \\
5 \\
\end{array}$ & $\begin{array}{l}5 \\
3 \\
5 \\
- \\
\end{array}$ & $\begin{array}{r}1 \\
10 \\
2 \\
3 \\
\end{array}$ & $\begin{array}{l}27 \\
28 \\
32 \\
4 \\
\end{array}$ & $\begin{array}{l}2 \\
8 \\
9 \\
1 \\
\end{array}$ & $\begin{array}{r}1 \\
11 \\
5 \\
3 \\
\end{array}$ & $\begin{array}{r}6 \\
12 \\
13 \\
1 \\
\end{array}$ & $\begin{array}{l}4 \\
2 \\
3 \\
1 \\
\end{array}$ & $\begin{array}{l}8 \\
9 \\
4 \\
2 \\
\end{array}$ \\
\hline TOTAL- & 3 & 76 & 13 & 16 & 91 & 20 & 20 & 32 & 10 & 23 \\
\hline
\end{tabular}

Sources Department of Planning and Urban Development. 1976. All of the above tables and data are dispersed in various City departments in a format that meets that individual 
department's specific needs. This demonstrates the City's need for a data collection system that would allow easier access and manipulation of information for analysis of disinvestment. Trends could be identified and proper actions taken before the situation became hopeless. The cumulative cycles mean less tax revenue, more vacant land, and because of speculations, a lesser chance of an economic turnabout without massive government aid for assembladge of marketable parcels.

\section{Land Banking: A Revitalization Tool:}

Since the City has been unable to stop disinvestment with it's present redevelopment policies, an alternative policy might be to acquire tax delinquent and tax reverted properties and land bank them until the disinvestment cycle comes to an end. New money can then be pumped into the area by selling large marketable parcels for a reuse that is compatible with the newer functions and needs of the city and disinvested areas.

Land banking in areas of disinvestment would offer the City a new and needed revitalization tool that is flexible enough to assist other City redevelopment programs. By assembling land in disinvested areas an opportunity is presented to create new areas for future city growth.

It must be remembered that while land values may be falling in certain areas of the city, land is becoming a rare and costly commodity in metropolitan areas. Low density developments in the suburbs, have caused the cost of public 
services to rise at a rapid rate. 30 with further

suburban development now being constrained by commuting distance from the central city, and with transportation and energy costs rising, the city is presented with an opportunity to recapture middle and upper income families whom it needs for economic vitality.

If there is to be a rejuvenation of the City, many changes must occurl however, there can be no change or new growth without sufficient land. New consumer preferences in housing require amenities, parks and open spaces; modern manufacturing is now done in ground level plants. All these activities require land. A central city land bank could act as one of the tools to accommodate this opportunity for redevelopment. The private market and speculation carnot. Owners of individual and scattered properties are individually powerless to make any meaningful development of their property. When there is a potential for development, it is the speculators who demand extravagant prices that prevent development. Only the city can develop a policy, obtain the legal powers, and provide the necessary amenities and services that can break the disinvestment cycle.

The existence of large areas of vacant land in the city, as destructive a force as it is, can instead represent a future city resource. It is of utmost importance that the potential opportunity be realized, the past mistakes of our cities have been too many. A flagrant example is the

30Hor further detail see: U.S. Dept. HUD et al. The Costs of Spraw1. Washington, D.C. U.S. Government Printing office. 1974. 
development of Staten Island. New York City had acquired large amounts of land through tax foreclosures in the 1920's and $30^{\circ} \mathrm{s}$. This gave the city a superb chance to gain open space and ensure orderly development as building pressures developed after the War. However, the City threw away the opportunity by selling the parcels in fragments. As a consequence obsolete street patterns planned for defunct subdivisions laid the development pattern. ${ }^{31}$

Other examples of lost opportunities can be seen in many urban renewal programs in our cities. Since urban renewal is supposed to be a short term program and because of public impatience for redevelopment, many marginal developments have been constructed that add very little to the city's future vitality. A better alternative may have been to land bank the projects until a more optimum development could have been obtained. City officials must realize that redevelopment of a city is an enormous task. These things take time and do not occur spontaneously. However, this time $\operatorname{lag}$ is short in relation to the life of a city. A policy which sets land in reserve until other city development incentives can attract more optimum or needed development, could in many cases better serve the future of our cities.

St. Louis Land Banking, An Example

The St. Louis land banking program is one of the few,

31Whyte, William H. The Lost landscape (Doubleday \& Co.) 1968, p. 67. 
if not the only inner city land banks in the united States. This land bank requires discussion, as an example of what a land bank can accomplish in a short period of time. Like any example, it can be useful to the city of providence as a basis for duplication or expansion. 32

The St. Louis Land Reutilization Authority (L.R.A.) evolved in 1971 out of a desire of the Mayor of St. Louis, Alphonse Cervantes. He wanted to inventory municipally owned property in the City, and to also do something about the City's alarming increase in delinquent taxes. (Ihe tax delinquency rate increased from 2 to 9 percent between 1965-1970). Although the I.R.A. was set up to remedy a delinquent tax problem, it became obvious that the process of foreclosing tax liens would result in a sizeable inventory of land, $(12,000-14,000$ properties in 1970) and thus a significant new economic resource for the city. While not given the power of condemnation, the L.R.A. has the s.tatutory power to assemble tracts by trade or exchange of parcels in it's inventory. In two years of operation, the Agency has acquired an inventory of 5,000 parcels. Coordination with city planning and other development agencies determine the disposition of the properties. The accomplishments of the L.R.A. have been diverse. It has implemented a homesteading program by selling residential properties at a minimum cost to those who agree to rehabilitate the structures. It has developed an inventory of 
land for future city growth and expansion, encompassing both industrial, residential, commercial and public uses. The L.R.A. also has adopted an informal policy of making land adjacent to commercial/industrial facilities, available for expansion and parking purposes.

33.

Perhaps the most unique and useful element of the I.R.A. is the way it works with other redevelopment agencies in the City. These agencies like the L.R.A. were created as development incentives to meet the economic needs of the City. A brief summary of these agencies is as follows:

1) The Land Clearance Authority: has been the City's urban renewal authority for 24 years. It also has powers to act in non-federally assisted urban renewal areas. Under Community Development grants, the Authority has become more of a city agency, being more dependent on Local decision making. Of significance is it's condemnation powers.

2) The Missouri Redevelopment Law, This is the most commonly used of the City's development tools. The statute gives private redevelopment corporations substantial incentives to develop in areas designated by a plan approved by the City. Redevelopment corporations whose plans have been approved, are given the power of eminent domain for condemnation within the redevelopment area. Tax abatements on a declining scale are also given. Since 1955, close to\$l billion of improvements have been constructed in the city under this statute.

3) The Planned Industrial Expansion Law (P.I.E.): The Missouri Supreme Court recently upheld the constitutionality of this law. It allows the St. Louis Planned Industrial Expansion Authority (P.I.E. Authority) to issue revenue bonds to finance industrial construction and rehabilitation. The P.I.E. Authority can only function in areas the City designates as blighted, undeveloped, or unsanitary and only pursuant to an approved development plan.

33Rochester, N.Y. also carries out a similar informal policy, in its Department of Community Development. While no formal Land banking program exists, the Department reserves urban renewal and tax foreclosed land for future expansion of existing industries (interview between J. Seymour and John Stockton, Director of Economic Development $6 / 30 / 76)$. 
The St. Louis Franklin Industrial Park is an example of how these development incentives can cooperate to achieve development. The 20 acre site is located in a model cities area. The Federal Economic Development Administration (EDA) offered St. Louis $\$ 1.1$ million to develop a pilot industrial park in this area. The P.I.E. Authority will act as a developer of the project in agreement with the Land Clearance Authority, which will act as agent for P.I.E. in the acquisition of buildings, and relocation of residents and business. Significantly $40 \%$ of the land in the project area is owned by the Land Reutilization Authority, who will sell the land to P.I.E. for a negotiated written down price. P.I.E. and the Economic Development Division (the agent for the Missouri Redevelopment Law) will seek industrial firms to construct new facilities or to lease facilities constructed by P.I.E. In both cases the purchaser or Lessee will be able to make use of the tax abatements provided in the Redevelopment Law.

There is no question that the combination of the L.R.A. and the other three development incentives have greatly enhanced the recycling of city land. Currently, (Nov. 1975), a redevelopment corporation is undertaking a 185 acre project consisting of 1,500 new housing units, new commercial and industrial development and expansion of a medical complex. This huge project is utilizing a $\perp$ four development incentives. The I.R.A, has made available several properties in the area. In another development the Home Builders Association has 
submitted to the city a plan for a new residential community in midtown St. Louis of 2,500 units. The L.R.A., having anticipated submission of this plan has been land banking in the area and owns 50\% of the land which will be made available.

Many parallels can be drawn in this case study between the characteristics of St. Louis and Providence. Upper South Providence provides an example. Much of the area is vacant and in fragmented ownership. However, on the positive side there are existing industries, and a major hospital, which can represent a potential for future revitalization. Certainly Brown University's new medical school will seek new facilities. Moreover, the City's jewelry industry seeks expansion. In addition, new housing is always sought. To achieve developments requires public incentives, and a basic ingredient- an availability of land: As in st. Louis, a land bank offers a mechanism that would insure that this basic ingredient is available.

In summary, disinvestment trends are evident in the City, as seen by the declining population, growing tax delinquencies, and demolition trends. Land banking can present an alternative for the interim use of land left vacant as a result of this disinvestment. The St. Louis experience is an example of how another city used this tool. The city of Providence should likewise seriously consider land banking as a redevelopment tool. 
In order to consider implementing a land bank program in the City, goals and objectives will be proposed and strategies for implementation discussed. However, first it is necessary to consider certain legal issues that may be pertinent to a land bank. This will be done in the next Chapter. 
THE LEGAL BASIS FOR LAND BANKING

Before the city implements a land banking program, certain Legal questions must be considered. This is necessary to determine the legality of the issues, and to obtain judicial direction as to what goals, objectives and strategies may be employed in implementing a program.

If a redevelopment program is innovative, such as land banking is, there may not be specific court precedent or enabling legislation that can provide direction. In this case, guidance is obtained by Looking at Court cases that contain issues similar to those in a land banking program. From this framework enabling legislation can be drafted that meets or approximates previous policies set down by the courts.

This Chapter focuses on three key issues that may be of concern to an inner city land banking program: 34

(1) Can eminent domain be used as an acquisition strategy?

(2) Could existing agencles that have the power of eminent domain (for example, an urban renewal agency) condemn land for the Land bank?

34 These issues a 11 focus on the acquisition of land. which is the overall objective of a land bank. Other legal issues could also be raised in the course of program implementation. For example, if part of the financing of a land bank required bond issues, the constitutional limits of bond issues would have to be researched, and provisions made accordingly. Similarly. legal requirements for land disposition procedures would also have to be researched. These issues will not be discussed in this report, but would have to be considered before the city proceeded in establishing a land bank. 
(3) Does land acquired by condemnation have to be for a specific use, and how far into the future can this land be held and still be justified as being acquired in the public interest?

A discussion of these issues follows.

1. Eminent Domain:

The power of eminent domain would be an important tool for land acquisition. First, it serves as an aid to facilitate negotiation. The property owner knows that the City has the power to acquire the property, therefore, the negotiation can focus on "just compensation." Second. eminent domain is necessary for acquisition of those properties whose market value cannot be agreed upon, but whose acquisition is vital to the goal of assembling a marketable disposition package for future use.

Eminent domain has been defined as, "the power, inherent in a sovereign state, of taking or authorizing the taking of any property within its jurisdiction for the pubdic good." 35 The use of eminent domain is limited in both the federal and Rhode Island Constitutions. The Fifth Admendment to the United States Constitution states that private property "shall not be taken for public use without just compensation." The Fourteenth Admendment also binds the states from taking property for private use; 36

35J. Lewis, Eminent Domain sec. 1 (3d Ed. 1909) Boom Co. V Patterson 98 U.S. 403, 406 (1878) ("E'minent Domain requires no constitutional recognition; it is an attribute of soverignty") as cited in Fishman op. cit, pp 948, 949. 36Fishman op cit pg. 949, Missouri Pac, Ry V Nebraska, 164 U.S. $403(1896)$. 
"No state shall deprive any person of life, liberty or property without due process of Law." The Rhode Island Constitution states "private property shall not be taken for public use without just compensation." 37

Based on these constitutional restrictions the key issue in the use of eminent domain for a land banking program is, What constitutes a public use? The concept of public use has been defined in a history of case law in both the Federal and State courts. The Courts have repeatedly been called upon to settle challanges to federal and state statutes that have been progressively expanding the public use concept. Therefore, inorder to research the public use issue we will do the following.

1) Review Federal and Rhode Island Court cases to see what the court has determined to be a public use.

2) Look at cases that have facts and issues that parallel an inner city land banking concept, (cases involving vacant unassembled land in a blighted or disinvested area).

Federal Court Review:

The role of the Federal courts in urban redevelopment has been limited until the late $1930^{\circ} \mathrm{s}$. During this period federal housing and redevelopment legislation was initiated. Since then, both federal programs and court cases have increased. Certain Constitutional Rights and Princple - sec. 16. 
Berman vs. Parker 348, U.S. 26, (1954) represents the major landmark case for establishing the parameters of public use in redevelopment programs. 38 In this case, the Supreme court upheld the use of eminent domain under the District of Columbia Redevelopment Act of 1945. The Berman case is significant because it is the supreme Court that is interpreting and expanding the issue as to what constitutes a public use, and how such public use is to be determined. Also, the Supreme court is acting in the role of the State Courts in that it is reviewing an issue involving congress acting as a legislative body for the District of Columbia.

In the case, the plaintiffs owned non-residential property, in sound condition, which was to be taken by the urban renewal project. They argued that the taking of sound property in order to develop a more attractive community, did not constitute a legitimate public purpose. The court rejected this argument, holding the District of Columbia Act constitutional. In deciding the case, the Court set guidelines on the role and extent of the legislature in determining the public use or public interest.

38It was first held in U.S. V Certain Lands in City of Louisvilie, $78 \mathrm{~F} 2 \mathrm{~d} 684$ (6th Cir. 19.35) that the federal government could not condemn lands under a public housing program. However, in 1938, the Tenth Circuit Court of Appeals in Oklahoma City V Sanders 94, F 2d 323 (1938), upheld the states rights to condemn property for federally aided public housing. In 1954, in Kaskel $v$ Impellitorpi 347. U.S. 234, the supreme Court denied Certiorari and uphedd the New York State Court ruling that the eradication of slums was in itself a sufficient public use to justify the employment of eminent domain, irrespective of the ultimate reuse of the condemned land. 
'The Court stated:

"The legislature, not the judiciary is the main guardian of the public needs to be served by social legislation, whether it be Congress legislating concerning the District of Columbia, or the States legislating concerning local affairs. This principle admits of no exception merely because the power of eminent domain is involved." ('Supra pg. 32)

Regarding the use of eminent domain and the subsequent reuse of property the court said,

"The Court cannot say that public ownership is the sole method of promoting the public purposes of a community redevelopment project, and it is not beyond the power of Congress to utilize and agency of private enterprize for this purpose or to authorize the taking of private property and its resale or lease to the same or other private parties...". (pg 34).

As to the boundaries of a project or the classification

of buildings that may be taken the court ruled:

"Once the public purpose is established, the amount and character of the land to be taken and the need for a particular tract to complete the integrated plan rests in the direction of the legislature. If the redevelopment agency considers it necessary to take full title to the land, as distinguished from the objectionable buildings located thereon, it may do so.... The rights of property owners are satisfied when they receive just compensation which the Fifth Admendment exacts as the price of the taking." (Supra pg. 35.36)

In summary, the significance of this case to a land banking program is that eminent domain can be used if it is in the public interest; what is the public interest is to a large degree based on a legislative determination of public need. Further, the eventual reuse of the property need not be public ownership, to justify the use of eminent domain. Finally, the amount and nature of land to be taken, is a local determination, but must be based on a plan. However, 
it must be distinguished that in the Berman case, the Court is reviewing a challenge to an urban renewal project. While this difference does not prohibit this precedent for establishing a basis to determining the public interest, it may be constraining regarding the character of the land to be taken. It must be remembered that land banking is appropriate for largely vacant areas. In contrast, urban renewal, has been mainly concerned with improved areas that are blighted. However, there are court decisions that support this difference as still being in the public interest.

In People ex rel. Gutknecht v. Chicago, 3 Ill. 2 d, 539. 121 N.E. 2 d. 791 (1954), the supreme Court of Illinois approved legislation authorizing the exercise of eminent domain for redevelopment of predominately "open" areas which were unmarketable for decent housing and seemed destined to become slums themselves. The court held that the power of eminent domain could be used not only to eliminate slums but to prevent them as well.

In Redevelopment Agency of San Francisco v. Hayes, 122 Cal. App. 2 d 777, (1954), a California district Court of Appeals upheld a program to convert a blighted area which was 85 percent vacant into a predominately residential neighborhood containing open space and commercial, public, institutional and community facilities. The court stated: "ro hold that...redevelopment of such areas as
contemplated here not a public use, is to view
present day conditions under myopic eyes of years
now gone by." (Supra at 803) In an appeal, the U.S. Supreme court denied a petition for writ of cetiorari to the California court, thus upholding 
the case. ( 348 U.S. 897, 1954).

Another relevant case is Cannata v City of New York 11 N.Y. 2 d 210,182 N.E. 2 d 395 (1962). Here the plaintiffs sought a declaratory judgement for the unconstitutionality of sec. $72-n$ of the New York General Municipal Law, c. 24. The section authorized cities to condemn for the purpose of reclamation or redevelopment of predominately vacant areas which are economically dead, so that their existence and condition impairs the growth of the community and tends to develop blighted areas. Among the conditions identified by the statute were poorly subdivided lots, poorly designed street patterns, scattered improvements, and obsolete buildings. The statute also declares that private land assembly for redevelopment in such areas is difficult, that the conditions create tax delinquency and impair sound community growth.

Following the mandate of Berman $v$ parker the court saids
"An area does not have to be a slum to make it's redevelopment a public use nor is public use negated by a plan to turn a predominatly vacant, poorly developed and organized area into a site for new industrial buildings. We see nothing unconstitutional on the face of this statute or its application to the facts." (Supra 215)

One Justice dissented in the decision on the basis of the indefiniteness of the statute. An appeal to the U.S. Supreme Court was dismissed for want of a substantial federal question.

Thus, there is a substantial precedent for taking vacant areas that are blighted or have the potential of becoming 
blighted. Areas that are both vacant and blighted should present an even stronger case.

Rhode Island Courts and Legislation:

To propose a City land banking program with the power of eminent domain will also have to be able to withstand a review of the Rhode Is Land Courts.

The judicial history of the concept of public use in Rhode Island has been progressively expanded. This is exemplified in an opinion to the Govenor by the supreme Court of Rhode Is land ( 308 A 2d 809. August 8, 1973). The Govenor requested the Courts opinion on the creation of the Khode Island Housing and Mortgage Finance Corporation, specifically; did the Act serve a public purpose. In response, the Court cited Romeo v Cranston Redevelopment Agency 105 RI 651. 254 A 2d 426 (1969), where the Court attempted to describe the requisite "public use" that permits acquisition of private property by eminent domain:

"Today... it is our belief that a public use may not be given a rigid unbending, absolute definition. In the everchanging conditions of our modern society, new advances in the fields of sciences, new concepts in the scope and function of government and other circumstances make it clear that the former concept as to what is a public use, has undergone a great change. Views as to what constitutes a public use necessarily vary with the changing conceptions of the scope and functions of government so that today there are familiar examples of such use which years ago whould be unheard of. As governmental activities and services increased with the growing demands of society, the concept of "public use" has broadened in proportion thereto. The modern trend of authority is to expand and liberaliy construe the meaning of "public use." id. at $658,254 \mathrm{~A} 2 \mathrm{~d}$ at 431 .

The Romeo case (supra) also provides insight on the 
Courts view of condemning predominately vacant land for future redevelopment. In this case, the redevelopment agency was acquiring $14-1 / 2$ acres of land, of which 11 acres were vacant. The owner of the land sought an action to enjoin the agency from proceeding on the grounds that the urban renewal enabling legislation was unconstitutional. In the decision, the Court upheld the constitutionality of reclaiming predominately vacant land which was economically dormant. The court noted the similarity between the Rhode Island General Laws 45-31-8, and the Massachusetts General Laws, Chapter $121 \mathrm{~A}$ sec. 1, both of which deal with blighted open areas. 39 The court then cited the opinion of the Justices of the House of Representatives (334 Mass. 750) where the Massachusetts Court gave the opinion that the redevelopment of "blighted open areas" was a public purpose.

In summary, the Rhode Island Court has recognized an expanding use of eminent domain for public purpose. Based on the Romeo case (supra) and the Courts interpretation of blighted open areas, it appears that the use of eminent domain in a land bank program in blighted city areas would

39A "blighted open ar ea" defined in the Massachusetts General Laws, Chapter $121 \mathrm{~A} \mathrm{sec} 1$ is, "A predominately open area which is detrimental to health and welfare... because it is unduly costly to develop it soundly through the ordinary operations of private enterprise by reason of , ...obsolete...platting or subdivision, deterioration of site improvements or facilities, ... diversity of ownership of plots, ... or by reason of tax and special assessment delinquencies, ... or an abandonment or cessation of a previous use, ... or by reason of any combination of the foregoing or other conditions. 
be in the public interest. However, a legislative determination of this view should be made in the land banking enabling legislation. Such procedure is inferred in the Courts' Opinion to the Govenor (supra at 811), where the Court said, "In determining the presence of public purpose, we are cognizant that while legislative findings in this area are subject to judicial review such a determination is entitled to great deference by the judiciary ."

2. Obtaining the Power of Eminent Domain:

The power of eminent domain must be obtained by enabling legislation from the State. The city of Providence already has this power in many of its agencies and departments. 40 por administrative efficiency the city or land bank program might desire to use one of these departments, or agencies (such as urban renewal) to condemn land. Whether this is possible is of question. According to Nichols Eminent Domain sec 3. 211, the law is as follows:

The delegation of the power of eminent domain to a particular public or corporate body or to an officer or other person is, a personal trust and unless the legislature has provided for the redelegation of this power the party to whom such power has been delegated cannot assign or delegate it to anyone else." 41

40Dept. of Public Works; R.I. general Laws 1970 Reenactment, 24-8-5. Housing Authorities; Id. 45-29-6. Schools; Id, 16-9-5. Redevelopment Agency; Id. 45-32-5, and Article 33 of R.I. Constitution.

4ladherence to this principle of law can be seen in R.I. Court decisions In 1886 in a case concerning a conflict between authorities in locating a school house, the Court ruled: "a delegated power of condemning property must 
Thus, any agency such as urban renewal may be able to

delegate its power or acquire land on behalf of a land bank if its enabling legislation was amended. However the enabling Legislation granting urban renewal its original powers was for a specified purpose and along the lines of a rederal Program. Iand banking while being a redevelopment tool, has different objectives. 'lhe safest method to secure administrative coordination, would be to obtain separate enabling legislation for a land bank. One of the city's departments or agencies could then administer the program.

\section{Acquisition for Future Use:}

The preceding cases that were used to analyze the public use concept have been concerned with acquisition of blighted Land for specific reuses, with redevelopment to follow shortly after acquisition. In contrast a land bank does not seek immediate redevelopment, and may or may not, have a specific reuse. In some instances land may be banked for a specific future reuse such as housing or industry. In other instances the goal may be to bank land to control blight and reserve the land until the private market can be attracted to provide optimum development. The problem that may arise is the Courts may object to a proposed acquisition on the grounds that the intended reuse and time of reuse is too remote.

be exercised strictly in accordance with the terms of its delegation (Howland $v$ School District 15 K.I. 184) In 1958 in the matter of Bristol county Water Co. v Oliviera, 87 R.I. 356, the Court cited Nichols Delegation of the power of eminent domain to a particular public or corporate body ... is a personal trust and cannot be redelegated. 
This researcher has been able to find little case material in relation to these issues. The closest factual case is the matter of Commonwea 1 th of Puerto Rico v. Rosso 95 P.R. 488. (1967) cited earlier in this report. It is significant in that the supreme court of puerto kico upheld the validity of a Puerto kican statute authorizing land banking. The land bank was authorized to acquire any land in the path of urban development and to keep such land in reserve or to resell it for any sort of public or private redevelopment. 42

There are related cases where the main issue is advanced acquisition, but the land reuse has been specified.

\section{In Carlor v. Miami 62 so 2 d 897, (1953) the City} was charged by the plaintiff with fraud. The city had taken land in advance of need for a proposed airport and then at a later date sought a different use. The Florida supreme Court held there was no fraud and the city was within the public interest to plan ahead. The court stated:

"It is not necessary that a political subdivision of the State have on hand plans and specifications prepared and al1 other preparations necessary for construction before it can determine the necessity for taking private property for a public purpose... It is the duty of public officials to look to the future and plan for the future. City officials would have been derelict in the performance of their duties had they planned only for the necessities of 10 years ago without any consideration for the necessities of the future".

In Dade Co. v. Paxson $270 \mathrm{~S} 2 \mathrm{~d} 459$, the County was acquiring land in advance for a future park. The plaintiff argued that the county failed to show that the plans would be implemented, or that the park was a necessity.

42Sylvan Kamm, Land Banking, Public Policy Alternatives and Dilemmas, (Washington, D.C. The Urban Institute, 1970), pg. 20, citing Fred D. Bosselman, Alternatives to Urban Spraw 1 Legal Guidelines for Governmental Action. (National Commission on Urban Problems, Kesearch Report No. I5, Washington, D.C. ' 1968) 
The District Court ruled that it is not required to show an immediate need for the property and cited the Carlor case "It is the duty of public officials to look to the future and plan for the future..."

nhere are cases where the Courts have invalidated the acquisition of property for future use. In cases researched by the author, the reasons for which the court invalidated where, excessive acquisition for individual projects, future acquisition for financial savings 43 and "freezing land" for future development by withholding a permit. 44 These issues would not be found in an inner city land bank program whose main objectives were the control or elimination of blight and the future revitalization of the inner city area.

In summary, there is precedent that the courts will uphold acquisition for future use, and that the use for which the land was acquired need not be adhered to. In the puerto Rico case future acquisition for an unspecified use was upheld. While it may be argued that puerto Rican law is of Spanish root, the United States Supreme Court dismissed an appeal of the case for want of a substantial question.

43 In the matter of Board of Education V Baczewski 65 NW 2d 810 (1954).

44 In the matter of state ex rel, Sun oil co. V. City of Euclid $130 \mathrm{~N} . \mathrm{E} .2 \mathrm{~d} 336$.

45Rosso V Puerto Rico, 393 U.S. 14 (1968) (per curiam) 
"Presumably then, the Supreme Court of the United States is in full agreement with the High Court of Puerto Rico." 46 Finally it should be noted that urban renewal specifies land reuse and seeks development as soon as possible. However, many projects have laid vacant for ten years or more, and the land reuse is constantly under change.

Chapter Conclusion:

There appears to be sufficient court precedent to uphold the use of eminent domain in a central city land bank. However, it may be that a land bank could pass a Court review only if it followed the directives or principles previously established by the Courts. Therefore, these principles should be included or addressed by state enabling legislation which the city would have to obtain to undertake a land bank program. Based on the issues considered in this chapter, some of the provisions that should be provided in the enabling legislation are as follows: Enabling legislation should provide the land bank with the power of eminent domain. In order to delegate this power, it would be necessary for the legislature to determine that land banking is in the public interest and is a public need. The legislation should include a statement to this effect.

The enabling legislation should establish and define

460pinion of Richard P. Fishman and Robert D. Gross, in "Note Public Land Banking: A New Praxis for Urban Growth", (23 Case W. Res. Law Rev. 897, 1972) p 961. 
under what conditions, and for what purposes land could be banked. For example, definitions as to the character of land that may be taken should be made. The enabling legislation should establish and define the procedural requirements and functions of a land bank. For example, the authority and procedures to acquire, hold, manage, and dispose of land should be made.

Finally the enabling legislation should require a land banking plan. Some elements that should be required in the plan ares (a) the goals and objectives of the plan, (b) a deliniation of the land bank's boundaries, (c) proposed land uses in the land bank, or in the case where proper redevelopment cannot be determined, procedures for making the determination at a later date, and (d) disposition procedures.

A final point in this conclusion; should the City seek judicial certitude for a land bank program, then it should pursue an advisory opinion from the state supreme Court via the Governor or General Assembly pursuant to Admendment 12. Section 2, of the State Constitution. 
Discussion in the previous Chapters has considered the concept of land banking, disinvestment in providence, the use of land banking as a revitalization tool, and certain legal issues that should be considered before executing a program. The purpose of this chapter is to propose goals and objectives that the city may want to consider in a land bank program, and to suggest requirements and strategies to implementing a land banking program. The following topics will be discussed: goals and objectives, operational framework, strategies for acquisition, site selection criteria, financing sources, property management and and disposition considerations.

Section 1. Goals and Objectives:

Goals and objectives must be developed or assigned with the organization whose responsibility is to effectuate them. It is not the purpose of this report to develop goals in this context. This would be a task for the City. However, it is necessary to propose goals to expand the concept of land banking as it could apply to the city's needs. In this regard, the following represent goals and objectives that the City of providence might include in a land banking program.

A) Provide an opportunity for the efficient and orderly redevelopment of blighted City land-an unfortunate phenomenon, that if properly regulated can be transferred into an 
asset.

- Individual speculators and pockets of blight prevent land development or cause it to occur in a fragmented and haphazard manner. Larger holdings of public land would allow larger or smaller development in accordance with an overall plan.

B) Assemble and reparcel scattered pockets of decay for short range redevelopment.

-This would in effect help perfect the land market. A $20^{\circ} X 100^{\prime}$ lot when vacant becomes a trash heap. A $100^{\circ} X 100^{\circ}$ parcel presents an opportunity for a play area or a parking lot.

C) Assemble and reparcel large blighted areas for long, range redevelopment in areas where there is a high degree of disinvestment.

-Such areas should provide a City asset to meet the particular growth needs of the City, it's neighborhoods and it's residents.

D) Provide an alternative to marginal redevelopment.

-A land banking program would publicly acknowledge land as a valuable resource. Should certain proposals for development be considered marginal, a land banking policy provides an alternative until proper development can be found.

E) Provide land for construction of new housing.

-The City needs land to develop moderate and upper income housing to create a captive market to support a large economic base. The city also needs lower priced land to keep the cost of low income housing down so a better quality of housing with greater amenities can be provided for these residents.

F) Provide a vehicle for a homesteading program.

- Abandoned and tax delinquent property acquired by the land authority, could be sold at a low cost to families able to rehabilitate these structures with financial ald. Homesteading areas should be designated in relation to an overall neighborhood redevelopment plan. 
G) Provide land for industrial expansion by City firms, and provide a potential for the location of new firms.

H) Provide land for open space and recreation on a small and moderate scale.

- City neighborhoods need small and medium sized playgrounds and open areas. New developments require the same to enhance their marketability.

I) Provide land for future public facilities.

-An acquisition program that reserves land for public reuse in accordance with a City development plan, precludes the costs of future price escalation, land assembly and demolition.

J) Provide a statement of public policy for disinvested areas.

-A land banking program with publicly recognized goals, that assisted other redevelopment agencies, would help stabilize abandonment and restore investor confidence to the City. Owner occupants and investors would be encouraged to keep up their properties where redevelopment objectives were consistent with present property use. Incompatible uses would be designated for conversion or acquisition by the land bank or other redevelopment authorities.

K) Provide a deterrent to tax delinquency

- Land banking offers an alternative to the city tax sale, which can eventually be redeemed if the property again becomes valuable. With appropriate legislation, foreclosure by the land banking authority would mean loss of property title to those who do not pay within the time provided by law.

L) Realize a profit on certain land investments.

- Land prices are naturally enhanced when new public and private facilities are established nearby. By ownership of these adjacent parcels the City would realize an increase in the value of land holdings which have occurred due to the City's policies and programs. 
Section 2. Operational Framework:

A land banking program could be organized as an autonimous agency, or part of an existing agency or City department or a combination of the above.

As an autonomous agency, a land banking authority could be appointed by the Mayor and/or City Council. Members might be drawn from various City groups or agencies that are involved in the social and economic advancement of the city. The authority in turn, could hire staff to carry the program. As a cost saving measure, the authority might utilize staff of City departments engaged in City revitalization, such as, Community Development Department, or Department of Planning and Urban Development. As an alternative to these two options, the Mayor and Council could conduct the program, using existing City staff or creating a new department. Many other potential combinations exist for the development of the program. The above are presented for conceptual purposes. The final choice should be made only after careful study. In making the determination, it is important to realize the potential interrelationships that can exist between the land banking program and the functions of other City revitalization agencies. The land banking program should be seen as a tool that provides the basic resource of land for economic and social development. Land is needed for programs by the Community Development Department, the Housing Authority, the khode Island Industrial Facilities Corporation, and other development agencies. Therefore, for a land bank to be effective, cooperation must 
be a major organizational objective.

Section 3. Acquisition Strategies

A goal of a land bank acquisition program should be to assemble land at the lowest possible cost and hold it until proper reuse markets can be established. There are a number of strategies that can be employed to do this. The strategy for eminent domain has previously been discussed; however, this should be a last resort. It is expensive and causes confrontation. The initial strategy for a land bank should be to assemble land that is free or available at a minimal cost. By combining unproductive City owned property, undeveloped urban renewal land, and acquiring tax reverted and tax delinquent land, the City can develop a substantial base for a land bank program. Initial research into the location of these properties, that are in or adjacent to disinvested areas, has been done for this report and is provided in this section. Also included are strategies for minimizing the cost of acquiring land in disinvested areas that is: privately owned.

\section{(A) City Owned Property:}

Table IV shows the concentration of land owned by the City that is in or adjacent to disinvested areas, and is not in public use; 522,075 square feet which represent 70 parcels or 11.8 acres of Land are available. This Land has been acquired by the city through such vehicles as donation, tax foreclosure or purchase. Wuch of the land is in disinvested areas and continued ownership is not desired 
Table IV

\section{CITY OWNED LAND IN OR ADJACENT TO DIS INVESTED AREAS THAT IS NOT IN PUBLIC USE IN 1975}
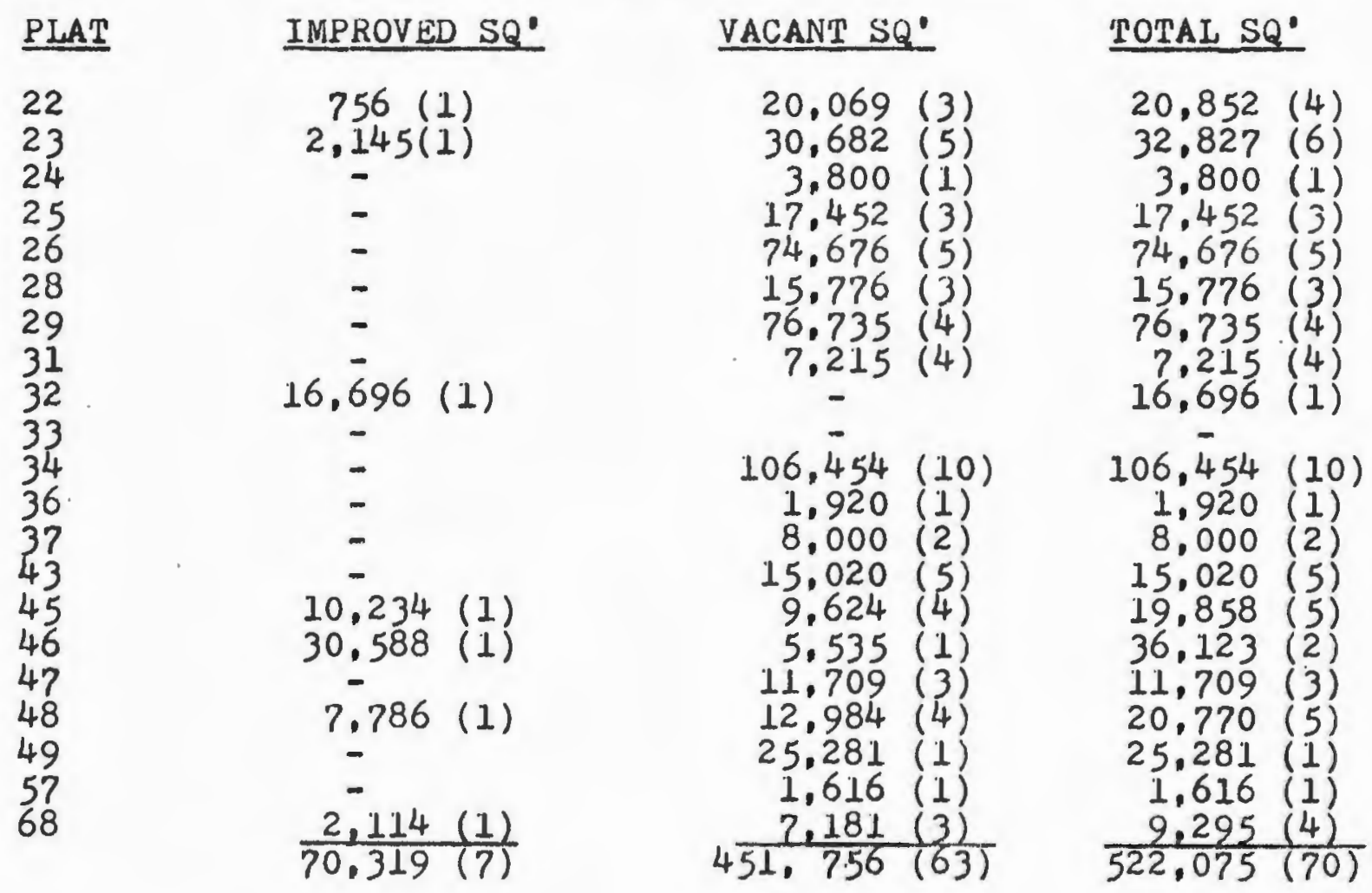

(11. 8 Acres)

() Number of Parcels

Sources Data compiled by Providence Department of Planning and Urban Development. 1975. 
by the City, however, according to the Planning Department, the City has no present policy for this land, and there is no significant demand for it.

Another major source of City land is public rights of way that would be abandoned if they were within a land bank. They represent a significant amount of land in a City area, for example, public rights of way represents $35.5 \%$ of the land area in Upper South Providence. 47

TABLE V

UNSOLD URBAN RENEWAL LAND AS OF OCT 13,1976

PROJECT:

RLAT LOCATION:

Comstock

East side Renewal $2,3,9,10,12,14,16,17,18$

Lockwood

Model Cities

48,54

8,5

Mount Hope

West Broadway

$32,33,35,36$

$$
24,25
$$

TOTAL

Source: Disposition Section, Department of Planning and Urban Development

(B) Urban kenewal Property:

Table V shows project and plat square footage of urban renewal land that has not been sold or developed in the city. There are 2,145,195 square feet or 49.3 acres

47Graduate Program in Community Planning, U.R.I. op. cit. Pg. 15.

\section{SQUARE FT. AVAILABLE,}

157,164

413,276

377,781

41,250

286,707

532,227

336,790

$2,145,195$ 
remaining. Map II combines both tables IV and $V$ to graphically depict this data and to summarize available city controlled land by plat. Major concentrations can be found in plats $5,25,32$ and 45 . These plats are in, or adjacent to disinvested areas. By acquiring blighted land adjacent to these projects, a large land bank could be assembled, also smaller concentrations, not in large disinvested areas could be for smaller land banks for future neighborhood facilities, parking, playgrounds or neighborhood commercial centers.

The Urban Renewal Agency is presently trying to dispose of its remaining land to close out its projects. A number of strategies are being used. In the comstock project, for example, individual lots are being sold for single family home construction. The danger in this type of disposition is that, in many cases, the development impact is not considered on an area wide or comprehensive basis. Redevelopment of individual parcels or isolated projects will not of themselves curb disinvestment and bring about revitalization. What is required is a comprehensive and larger scale approach that considers the area as a whole and appraises the functional needs and interrelationships. Should the market not have sifficient interest or confidence to provide a comprehensive development then it may be a more rational decision to land bank the land until sufficient capital can be generated. A marginal development undertaken only to close out a project or to put properties back on the tax roles presents the danger 
of itself becoming a blighting influence, thus further eroding investor confidence. Our cities cannot afford these costly experiments.

\section{(C) Tax Foreclosure:}

Foreclosure on tax reverted land offers another method for land acquisition. A scenerio of the present system of tax collection and the way tax title reverts to the City has been described in chapter. II. As was pointed out, tax reverted land ends up as dormant undevelopable land. Its conveyance and redevelopment is impired because of the difficulty in clearing title. There is little interest from the private sector for buying this land since it is usually found in disinvested areas. Map III shows the concentration of tax reverted land in City plats. As to be expected, the majority is found in disinvested areas, particularly plats $23,43,45,48,54$ and the surrounding areas. This map is particularly significant in that it shows the reversion trend over a two year period. In all but plat 34, the situation worsened. While the overall number of parcels reverted are not substantial in relation to the total plat. it must be remembered that tax reversion is the bottom line of disinvestment. The speculators are not even interested in buying the back taxes. Thus, if the reversions increase, the disinvestment is increasing in proportion.

Foreclosure on tax delinquent land also presents an opportunity for land assemblage. The City should stop selling delinquent taxes and foreclose on the properties for 
City ownership. Under the present system, back taxes are purchased by speculators who then hold a tax lien or institute foreclosure proceedings themselves. This only results in creating obstacles to clear title and it further fragments ownership in areas of disinvestment. This in turn, makes revitalization of the area more difficult. This process is costly to the city in comparison to the relatively small amount of revenue it receives at a tax sale. Moreover, many of the structures on these properties are demolished; thus, the City receives even less taxes from speculators in subsequent years.

An alternative to the present system would be to institute foreclosure proceedings on both tax reverted and tax delinquent land. In the latter case, either of two favorable outcomes could result, (a) taxes would be paid by the property owners sooner. A "get tough" policy on tax delinquent properties would inhibit abandonment, property owners would have to decide sooner, if they wanted to surrender their property to the city or maintain it. The present lengthy process creates a situation where delinquent taxes are accumulated and payment becomes more difficult. (b) the City would acquire the property for future revitalization of the area.

The stumbling block to this proposal is the present system for tax foreclosure, it is cumbersome, time consuming and expensive. Since foreclosure procedures could be the key 
component of a land banking acquisition program, a closer analysis is beneficial.

As discussed in Chapter II, when taxes are delinquent they are sold by the City at a tax sale. This procedure takes about two years from the date of the tax levy. To foreclose on property the owner of the tax title must wait at least one year after a tax sale to institute foreclosure proceedings. 48 The petitioner must pay all costs such as, court cost, attorney fees, title search and advertising expenses. After filing a petition for foreclosure, the petitioner must give notice to property owners and interested parties of the intent to foreclose. The owner of the property is given twenty days to respond, or such additional time as given by the court (this can be exhaustive considering Court backlogs and adjournments). The owner may at such time redeem the property by paying all back taxes, interest and petitioners costs the court deems reasonable. 50 If the redemption is not made or the court determines the property owner is not entitled to redemption then the Court will issue a decree barring the owner's rights to redemption.

The City may acquire clear title to property without going through foreclosure. However, this is only on parcels that in the opinion of the treasurer, are of insufficient

48 Rhode Is land General Laws 44-9-25). 49Ibid 44-9-26 \& 27). 50Ibid: 44-9-29). 
value to meet the tax liens on the property. Even in this case the City must wait one year from the date of tax reversion and then offer the parcels at public auction to the highest bidder, if there are no offers then the city can take clear title. 51

To solve these problems the City should seek legislation that would provide a more efficient foreclosure process for a land banking program. The legislation should specifically allow for foreclosures on tax delinquent properties and provide an expeditious foreclosure proceeding for both tax reverted and delinquent properties. Two cases support these points I In St. Louis the land banking authority statute provides for consdidated foreclosure suits (500 parcels at a time) which can be filed against properties on which liens have been placed for two or more years of delinquency. Also the statute provides for filing the action against the property "in rem" rather than against the record owner: Thus, the necessity of tracking down the owner is eliminated. These provisions mean that clear and marketable title can be obtained easier and quicker. ${ }^{52}$ A copy of the St. Louis land banking enabling legislation is provided in Appendix I.

Another example of legislation for tax foreclosure efficiency is the proposed legislation for the city of Providence's Homesteading Program. 53 The Homesteading 51 Ibid 44-9-36 and 38 . 52 National Council for Urban Economic Development, op. $\frac{\mathrm{c} i t}{53} \cdot \mathrm{pgg}_{\mathrm{b}} \cdot \frac{1}{76} \dot{0}_{1}$. 
Program has been deterred by acquiring abandoned property through the existing tax foreclosure laws. Also properties in tax title selected. by program participants have been redeemed by the original owner after improvements have been made. The proposed legislation allows the owner of tax title to make an immediate petition for foreclosure following tax sale, providing that the court finds the property abandoned. (See Appendix II for a copy of the proposed legislation.)

\section{(D) Vacant Land:}

Another strategy for land acquisition would be to purchase vacant private land in disinvested areas. This would be less expensive than acquiring improved land. Map IV. shows 31.951 .749 square feet (734 acres) of vacant land in the City in 1971. 54 Some of this land is in flood plains or in areas with greater than $15 \%$ slope. While the map reflects 1971 vacant land, the concentration can be seen that coincides with our outline of disinvested areas and areas of tax reversion and delinquency (refer to Map I and III of this report). In these areas the vacant land is a reflection and result of disinvestment.

Since 1971 vacant land in disinvested areas has increased at a steady rate. This can be supported by the growth in tax reverted properties from 1974 to 1976 (Map III) and by data from a study of Upper South Providence. The study concludes that in 1971, there were 24.3 acres of 54 Most recent available data from the Dept. of Planning and Urban Development. 

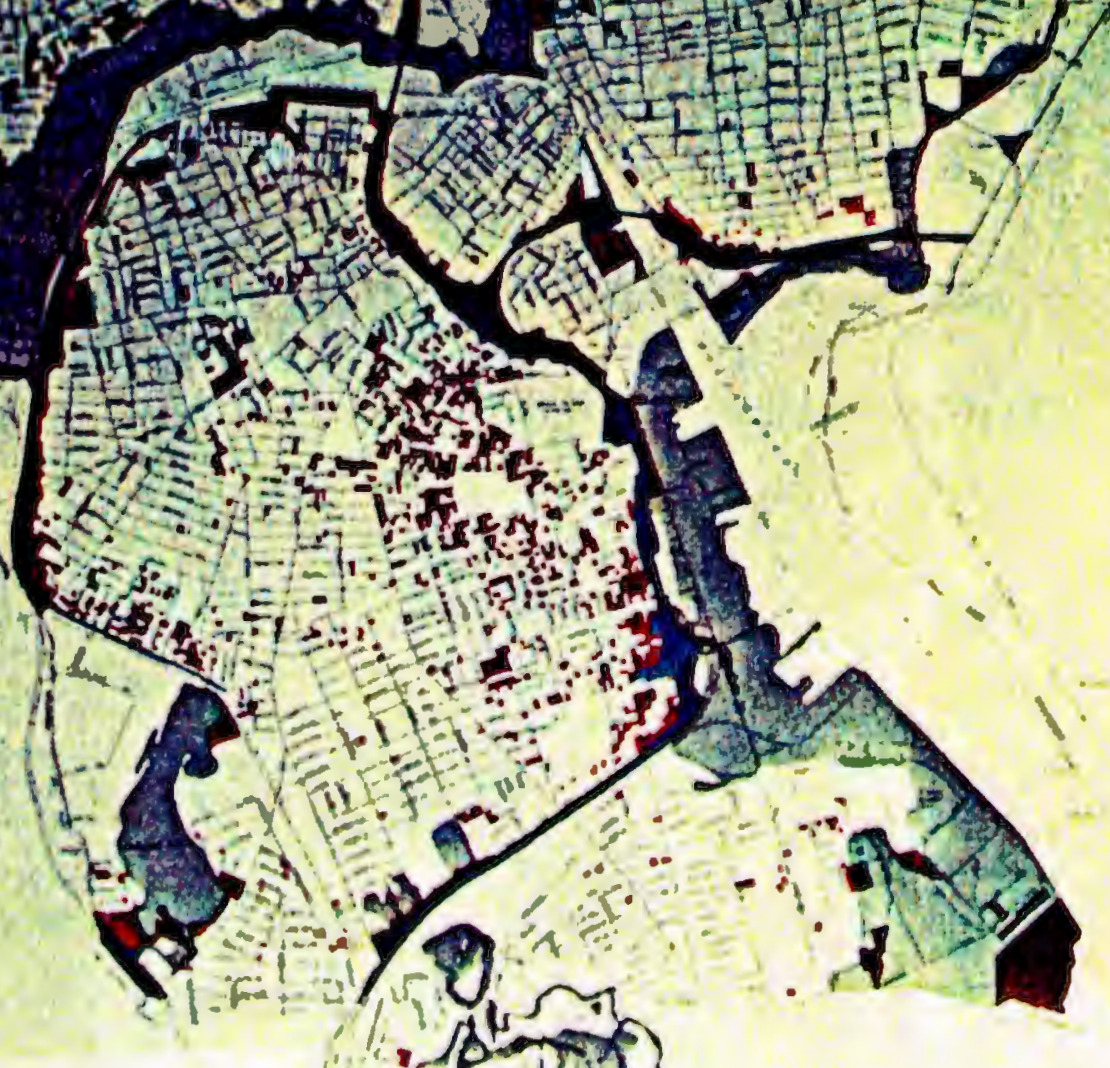
vacant land in this area; by 1976 there were 30.5 acres -

a $25.6 \%$ increase, similarly over the same period, structures decreased by $24 \%$. 55

In pursuing a vacant land acquisition strategy the City should also concentrate on the acquisition of those parcels that contain demolition liens. These liens are the result of the City demolishing the property because it was in violation of codes or was a fire hazard. In such instances the city would deduct the amount of the lien from the value of the property. This could result in substantial savings as well as recoup part of the City's lost investment, for example, in 1975 upper South Providence had 4.8 acres with demolition liens. 56 These ranged from approximately $\$ 800-$ $\$ 1000$ per demolition. 5 ?

(E) Other Acquisition Strategies:

So far in our acquisition strategy we have concentrated on acquiring or assembling parcels that the City has an economic interest in, or are vacant. However, these strategies cannot possibly be expected to assemble all of the parcels of a land bank. Acquisition of parcels in private ownership will be necessary to assemble a land bank that will be marketable. This does not mean though, that these parcels need to be purchased through fee-simple acquisition. Depending on the goals of a land bank there are numerous other strategies that can be employed that are cheaper for the Land bank and less disruptive to owners. A list of some pg. 17.18.

55Graduate Cirriculum in Community planning, U.K.I. op. cit. 56 Ibid pg 20.

57Data from interview with City Building Inspector, February 1976. 
of these techniques their benefits and applications, are as follows:

PURCHASE AND LEASE BACK, This involves acquiring property and leasing it back to the owner until it is needed for development. This tool allows the owner to negotiate the lease, saves him property taxes and gives him continued use. The City in turn, secures the land at present market value for future development and gradually recaptures its acquisition costs from the rent. A practical application could be where the owner is ambivalent about staying in the disinvested area. A purchase-lease back arrangement would allow him to compromise, that is sell at a fair market value now, thereby eliminating the chance of further property value decline, and lease back to maintain his present situation.

LIFE TENANCY: This is similar in concept to the preceeding method in that it allows the owner, after the sale of land to live free on the land for a period of time or for life. The advantages of this method are that it lowers the initial cash outlay to the purchaser in consideration for free rent. This tool would be applicable where a long term program is visualized.

INSTALLMENT PURCHASING, This involves, as its name implies, paying off the acquisition price in installments. It allows the buyer to keep his money productive for a longer period of time, while permitting transfer of title 
immediately. This would be advantageous where critical parcels were needed, but the City has a shortage of cash. The advantages to the seller are that it would allow him to spread his tax Liability over several years, as he is taxed only as he receives payment.

PURCHASE OPIIONS: This tool would give the holder the right to purchase the property according to the terms of the option. The purchase terms may vary especially in regard to purchase price and length of the option. This tool can be valuable for land banking when the land bank wants to forestall development, or prevent development of a particular use. If incompatible development was proposed for the site the city could exercise the option and purchase the land.

PREEMPTIVE PURCHASINGs This strategy would be used to stop undesirable development by purchasing strategically located parcels. These parcels would act as a barrier to certain types of development, thereby preserving the surrounding land from development unti 1 a more proper use could be determined. For example, by purchase of quilt-like patterns of land, the land bank could preempt any undesirable development that required large amounts of land.

OFl'ERING THE l'AIR MARKE'T VALUE: A land bank, that is unsuccessful in purchasing property for its fair market value, in effect removes the property from the market, since we can assume no one else is willing to offer a price above the fair market value. This technique is valuable where the land bank is seeking an orderly and comprehensive redevelopment and thus wants to limit fragmented development. At the time 
development is deemed appropriate the land bank can offer a nigher price, condemn, or let the major developer acquire the property.

TKANSFER OF CONDEMNATION AUTHORITY, A final acquisition strategy would be to allow redevelopers to condemn fragmented parcels that would be required for development. Implementation of this strategy would most likely be done when the land bank had assembled a sufficient number of parcels to make the land marketable for optimum development. This would save the City the expense of condemnation. This is not presently legal. However, a Bill has been introduced in the state Assembly that would grant developers these powers if the development was in the public interest. A copy of the Bill is in Appendix III.

In summary, the above section gives a variety of strategies and tools that can be used to assemble land. There is no particular combination that insures optimum success. What is required is imagination and innovation applied to the given situation which would keep financial costs at a minium, while attaining maximum benefits and goals.

Section 4. Site selection.

The selection of a site for a land banking program depends on a number of interrelated factors. The foremost factor is the goals and objectives desired by land banking as related to the feasibility in terms of financing, social costs, and political support. 
The analysis undertaken for developing an acquisition strategy clearly suggests South Providence (plats 23,45, 48 and 54) as the most likely place for a land bank on any large scale. South providence has the highest rate of tax reversion vacant land and disinvestment in the City. Further, the City has a vested interest in the area via outright ownership, and tax and demolition liens.

The optimum development or reuse for this area is difficult to ascertain. It has close proximity to the Central Business District, boarders industrial development, and has the largest hospital in the State within its geographic boundaries. Future growth or influence from any of these factors could spur numerous redevelopment uses in this area, particularly if the area was properly assembled for redevelopment. When considering the future of this area, the city might review a scenario for the area should land banking not be implemented. Lack of a comprehensive redevelopment plan for the entire area could lead to fragmented and marginal development which may only slow down the disinvestment cycle, or do little to revitalize the area. Most importantly, it would result in loss of a future opportunity for optimum development. The recent proposal for 300 low income housing units in an urban renewal project within this area is, in the opinion of the author, clearly an example of marginal development. The site is isolated in an abandoned and environmentally deficient area. There is no plan for future adjacent development, 
and the nature of the proposal is not characteristic of a catalyst needed to influence redevelopment. As an alternative, the City should pursue a land banking program so that the best interests of this area as well as the City can first be determined.

In addition to choosing a site for a large land banking program, there are a number of goals that could be met through spot land banking for both short or long time periods. Again, the site selection would be consistent with the related goals, and could occur throughout the City for example:

-scattered vacant parcels could be purchased and banked for future playgrounds, interium parking areas, or participation in a homesteading program.

- Larger parcels could be banked for future neighborhood facilities, which are not needed but will be as a neighborhood grows.

-vacant land adjacent to industries could be banked to reserve land for future industrial expansion. Such a policy would facilitate economic expansion and economic growth. Should economic growth not be eminent then the land exists for a new functional use for the area.

In summary, site selection could follow two strategies; Land banking should occur in disinvested areas until optimum development can be ascertained.

Land banking can be useful in neighborhoods by providing land for future public facilities, and future neighborhood 
improvements. Use of land banking in this instance, should rest on a neighborhood development plan.

Section 5. Financing.

The overall goal of a financing program is to keep costs at a minimum and if possible show a profit from sale of land to developers. The feasibility of accomplishing this task rests on the ingenuity and managerial ability of the land banking authority.

Many of the initial strategies have already been discussed, they include,

-Utilization of existing staff in City agencies for management and administration of the program.

-Drawing on existing City property interests for initial land assembly, specifically; city owned land not in public use, unsold urban renewal land, tax reverted and tax delinquent properties, properties with demolition liens, and streets that would be abandoned in the Land bank.

-Using various acquisition strategies in acquiring private lands, that cost less than fee simple acquisition but still achieve the goals of the program. The above strategies should be useful in keeping costs to a minimum. However, there will still be the cost for outright acquisition (property value, appraisals, title search and closing costs) as well as holding costs. (Property management, interest on Loans, taxes and some administration). The holding cost could be reduced by not 
paying an in lieu of tax payment on the acquired properties. This could be viewed as a subsidy from tax receiving entities. The need for cash will initially be great since revenues from the sale of land would not be realized for some time. Also an availability of liquid cash would allow the land bank to take advantage of unexpected opportunities for property acquisition. Some possible sources of funding or revenue for a land bank are as follows.

(A) Federal Sources:

The Community Development Program represents the greatest source of federal funds for City revitalization. The City has an entitlement of approximately $\$ 8.5$ million per year from this federal program. One of the eligible activities is the acquisition of real property that is "appropriate for ... the guidance of urban development. 58 Use of some of these funds for a land bank. should be considered by the city as an investment in future city growth.

rederal agencies also have funds available for demonstration projects that would advance knowledge in city revitalization. The Economic Development Administration provides in its Sec 302 Program, funding for economic development planning. The Housing and Community Development Act of 1974 provides for funding of "innovative projects." These are classified as "a project which encompasses a concept, system, or procedure that is unique, advances the state of the community development art and has the potential for transferability:" 59 Grants. Federal Register, Feb. 7. 1975. pg. 5955 Sec. 570.406. 
Sources such as these could be pursued in view of the uniqueness of a central land bank.

(B) Local Sources:

The degree to which local sources would have to be relied on is dependent on the success in obtaining outside funding as well as utilizing good management and planning in administration and land assembly. Financing from general tax revenues represents the easiest but least available source of funding. The City presently has little money to spare for innovative long term projects. However, at least for start up costs, the city may be required to provide funds from general appropriations.

Debt financing represents a more likely alternative to general appropriations. Under this method the City or land bank would be empowered to issue tax exempt, long term negotiable bonds to pay for its operating costs. The marketability of these bonds would be questionable if sponsored by a land bank authority, since the land bank has no taxing authority or financial history. There is also no guarantee that the revenues received would be sufficient to retire the bonds. Therefore, it would be imperative that any bond issues have the backing and full faith credit of the City and/or the state. Repayment of the bonds plus interest would have to come from revenue realized from the sale of land. Since this might not be sufficient, the City may have to consider other possible sources. For illustrative purposes these could include; special fees on real estate transfers, pooling of penalities on 
delinquent taxes, or numerous special use taxes.

As a financial management measure, the land bank should consider establishment of a capital reserve fund for bond retirement. The land bank would pay into this fund:

(1) All money received from various sources for the purose of the land bank.

(2) The proceeds from the sale of bonds.

(3) Proceeds from the sale of land banked land.

(4) Any other money made avallable to the land bank. The land bank would be allowed to withdraw from the fund only to the extent that the amount in reserve is sufficient to cover the principle and interest due on bonds in the succeeding year. 60

In summary, it would appear that a land bank would not be feasible unless money was diverted from federal funds coming into the City or new sources of federal funds were found. Local governments are in difficult financial positions with little money to spare. However, in evaluating the potential of a land bank program, the City cannot overlook the long term potential for increased revenues resulting from a successful land bank. orderly and optimum development means greater assessed valuation and higher taxes. It also means positive catalystic forces which while difficult to measure or attribute to, are unmistakably noticed. In this regard, the city should be willing to invest some of its resources for future revitalization. 
Section 6. Land Management:

Land management practices and policies for the holding time between acquisition and development is of particular concern to the people living or working in areas surrounding the land bank. Two major issues will have to be addressed by the land bank:

(1) Vacant land has a tendency to become a blighting influence on adjacent properties. Vacant land is physical evidence of the decay and disinvestment that has effected the area. It also becomes a receptacle for trash and debris generating an additional negative impact.

(2) Acquiring and reserving land for unknown future development, casts uncertainty on existing developments adjacent to the land bank. The future use of the land bank may not be compatible. Such uncertainty can discourage property maintenance and encourage sale or abandonment.

In addressing the first issue the following measures should be considered, A public relations program should be undertaken conveying to residents the goals of the land bank. Emphasis should be made on the fact that it represents a plan to eventually reverse the decay and disinvestment suffered in the area.

Property management practices should be undertaken that visably show the land bank to be an asset. The land should be graded, seeded and mowed regularly. Unnecessary thoroughfares should be closed of $f$, these only allow access for unloading trash and debris. Sections of the land bank should be reserved for interium use by residents. Lime for 
gardening or for marking baseba $\perp \perp$ lots is not an expensive und ertaking.

To safeguard against the uncertainty of the impact of future development, the land bank should undertake an informational program to inform residents of safeguards in the Land disposition program. This program would have to include measures to provide for an environmental assessment of any proposed development on surrounding neighborhoods. If the optimum development is considered incompatible, then compensating devices such as development setbacks or landscaping buffers could be incorporated in the development to negate the incompatibility. Should such devices not eliminate the problem then a last resort would be to either, require acquisition or the surrounding properties at fajr values or seek a more compatible development.

Section 7. Disposition of Land.

The disposition of land raises a number of issues. The foremost question is what should be the optimum reuse for the land and the time it should be offered for sale. As soon as there has been a sufficient amount of land assembled, pressures will come from various interest groups for redevelopment they deem appropriate. There most likely would be proponents for low income housing. This may be countered for demands for industry or retailing. This presents a dilemma; good housing is needed, but so are jobs. The greatest danger in these conflicts is that premature development would defeat the purpose of the 
Land bank.

The St. Louis Land bank program, referred to earlier, was given a grant by the U.S. Economic Development Administration to analyze its program. The study included an analysis of disposition strategies for economic development. The findings demonstrate potential problems. The study concluded that most of the land bank property was in residential areas, and as a practical matter, commercial and industrial reuse of land banked property would only occur in those districts specifically zoned industrial or commercial. For the land banking agency to have an expanded impact on economic development,large scale rezoning of land in land banking areas would have to occur. However, it was pointed out that this was not a likely possibility, recognizing both political and economic realities. One of the conclusions was that for the land bank to have any expanded impact on economic development, on a city wide basis, would require greater coordination between the land bank, public planning bodies and private developers.

Such a requirement would be necessary for a land bank in Providence. Cooperation would be necessary to determine the best use, and to pool resources and specialties to achieve that use. Close coordination should be made between the land bank entity, the Planning and Urban kedevelopment Agency, Community Development Department, homesteading program, Housing Authority and Rhode Is Land

6lNational Council for Urban Economic Development, ㅇp. cit. $\mathrm{pp}$. 15-16. 
Industrial Facilities Corporation. Depending on the administrative location of the land banking furction, it would be advantagous to have members of these agencies and departments serve as part of the governing body or review authority, for the land bank's disposition activities. This would insure involvement of key development officials and promote cooperation as well as coordination. As in St. Louis, the creation of a land bank would move the city to a time when it will have to more closely define its land use priorities. Determining the price of land to be sold would involve a number of competing objectives. In one instance, the land bank would want to use a low price as a marketing tool for optimum development. Investors have an ingrown bias towards disinvested areas. Hopefully the holding of land until disinvestment subsides and public policy is defined, would present the land bank as an opportunity and the fair market value or bidding could be used to determine the price. Should this not be the case, it may be necessary to use a low disposition price as a public subsidy to stimulate optimum development.

In competition with a low price strategy, is the need for the land bank to pay for its cost of operation. As previously discussed in Financing, the reliance on the sale of land for meeting acquisition and operation expenses depends on the degree of federal and local subsidies to the program.

To determine the proper price strategy, the land bank will have to evaluate the numerous factors involved at the 
time of disposition. Consideration will have to be made regarding the favorable impact on the city and adjacent areas, as compared to the demands of the developer. In consideration for a low disposition price, the City may be in a better position to require development controls or requirements from the developer. Examples of these controls or requirements could be; an area landscaping plan, a park development on part of the parcel, or a commitment by the developer to employ a certain percentage of low income workers in construction, or if the development is industrial, in future manufacturing. Finally, as an alternative disposition strategy the city could sell the land with the price to be determined on the success of the project. Numerous other situations or examples could be hypothesized where the price, may be best determined through various negotiation procedures. Therefore, it is important that in the land banking enabling legislation, considerable flexibility be given to determine the price of the land to be sold. For example, the land bank should have the option of determining the price via, appraisal, bidding, or by direct negotiation. 
CONCLUSION

The concept of central city land banking has been presented. Large disinvested areas that are applicable to land banking have been jdentified and a rationale given for smaller isolated land banks. Goals and objectives for land banking have been proposed, they are diverse and suggest the potential for the program. The strategies and procedures for implementing a land bank are complex and can present financial and administrative obstacles. However, in seeking solutions to difficult problems, tenacity, persistence and innovation is required. New revitalization programs must be sought, continued blight and disinvestment gives no alternative.

Disinvestment in any city is a powerful and complex force, its beginnings stem from great expectations and upward mobility as families migrate for a different living environment. What is left behind is the poor along with elements of prejudice, fear and alienation. such forces in society provide little hope for stability. Revitalization in these areas is a tremendous task. Past efforts have been criticized as too little and too late. However, there is question as to whether past efforts could be successful at all, in that disinvestment and blight, when solidly entrenched, may have to run its course.

The current revitalization efforts of the City, undertaken through Community Development Programs, appear to adopt a strategy aimed at preserving and strengthing neighborhoods which have the potential for economic and social stability. 
By enhancing the physical environment and providing needed services to the poor, it is hoped that private investment and citizen pride will remain, thereby maintaining the neighborhood. In contrast, disinvested areas like south Providence have been for all practical purposes abandoned. Given limited resources, choices must be made. It appears that the city has choosen areas where the most visable results can be obtained.

Given these resource allocation issues, land banking offers an alternative tool for revitalization of areas entrenched with disinvestment. With an acknowledgement of limited resources, land banking presents a positive statement for future opportunity. A land bank program would be a statement by the city that in effect says; through city policy and programs, future opportunities will develop and blighted areas will be revitalized. The reservation of land in a land bank will insure that optimum revitalization can occur. Such a position by the city would also present an alternative to marginal development which has a questionable impact in disinvested areas. Marginal development only slows down the disinvestment process, and in effect foregoes the opportunity for future optimum development. Given limited redevelopment funds, and skepticism of investors, a land bank gives the City and opportunity to maximize its revitalization efforts.

Land banking should not however, be seen as a revitalization tool in itself. It should rather be viewed as part of the process. Land banking only provides the essential 
ingredient of land. If a land bank program is to be undertaken then the city must develop other revitalization tools and procedures to compliment it. The following represents minimum requirements.

As an initial strategy the City should seek planning assistance, to help set up the land bank program. The City should pursue such sources as Economic Development Administration funds, 701 funds and HUD demonstration grants. The objective of this aid would be to develop a specific program, and procedures for implementation.

To maintain a measure on disinvestment trends, an information system would have to be developed in the City assessors and tax collectors offices, that could provide current data for key indicators vital to program decision making. By monitoring such indicators as tax delinquencies, abandonments, or demolitions, trends could be established. Decisions could then be made as to the boundaries of the land bank, and the treatment of peripheral areas.

To aid in achieving optimum development in land banked areas, a city department of economic development should be created that would be able to assist businesses in locating or expanding in the City. This department should provide a program of tax incentives and low interest long term financing that would encourage private investment.

Finally, and most importantly, communication and coordination between the city revitalization departments is essential. The Homesteading Program, Community Development 
Department, Department of Planning and Urban Development and other key departments should have input in establishing, program goals, developing priorities, and deciding on proper redevelopment. 


\section{BIBLIOGRAPHY}

American Law Institute. "A Model Land Development Code, Tenative uraft No. 6", 1974.

Babcock, Richard. "On Land Use Policy", Planning. June 1975.

Burroughs, Roy J. "Should Urban Land Be Publicly Owned?", Land Economics, 1966.

Connecticut Development Commission. "New Directions in Connecticut Planning Legislation", Land Use Controls, American society of Planning officials. 1968.

Fishman, Richard P. "Note Public Land Banking: A New Praxis for Urban Growth", 23 Case Western Reserve Law Review, 1972.

Fishman, Richard P. "Public Land Banking: Examination of A Management Technique", Management and Contro $\perp$ of Growth: Issues-Techniques-Problems-Trends-VoI III. The Urban Land Institute, Washington, D.C. 1975.

Fitch, Lyle C., and Mack, Ruth P. The Good Earth of America Planning our Land. Use, Chapter 6, "Iand Banking" . Prentice Hall, 1974.

Flechner, Harvey L. Land Banking in the Control of Urban Development, praeger, 1974.

Frank $\perp$ in, Herbert M., et al. In Zoning, Potomac Institute, 1975.

Graduate Curriculum in Community Planning.. "Northern South Providence Policy and Program Kecommendations for Community Development." Unpublished Planning, Report, The University of Rhode Island, 1976.

Hagman, Donald. "Public Acquisition and Disposal of Irands", Land Use Policies, American Society of Planning officials, 1970.

Haar, Charles M. "Two Federal Levers for Urban Use-Land Bank and Urbank," A paper presented before the House Banking Committee, June 1971.

Haar, Charles M. Land Use Planning, Little, Brown \& Co. 1971 .

Hartke, Vance. "Toward a National Growth Policy", 22 Catholic Law Keview. 1973.

HoLbein, Mary ELlizabeth. "Land Banking: Saving for a Rainy Day", planning. January 1975. 
Kamm, Sylvan. Land Banking: Public Policy Alternatives and Dilemmas, Washington, D.C.I the Urban Institute, 1970.

Letwin, william L. Municipal Land Banks: Land Keserve Policy for Urban Development, Unpublished Study, U.S. Dept. of Housing and Urban Development. 1969.

Mayer, Albert. "Iand as a Public Resource and Speculative Commodity", Architectural kecord, June 1970.

Morris, Eugene J. "The Quiet Revolution: Eminent Domain and Urban Redevelopment", American Bar Assoc. Journa 1 Vol 52, April 1966.

National Council for Urban Economic Development. Urban Land Recycling and Economic Development Policy in St. Louis. Washington, D.C.: Nov. 1975 .

New York Times, "Urban Land Bank Urged in Detroit:, July 26, 1975.

Parsons, Kermit C. "Canadian Land Banks", Keport 284. American Society of Planning officials, 1972.

Piedmont Iriad Council of Governments Land Bank Handbook: Advance Acquisition of sites for Low and Moderate Income Housing. Greensboro, N.C. 1972.

Priest, Donald E. "Techniques of Land Assembly for Central City Revitalization", forum One, "The Urban Land Institute, (no date).

Philadelphia Housing Development Corporation, Philadelphia Industrial Land Bank Plan, 1966.

Reps, John W.., "The Future of American Planning, Requiem or Renascence", Land Use Controls Vo1 1, No. 2, 1967.

Shoup, Donald C., and Mack, Ruth P. Advance Land Acquisition by Local Governments. New York: Institute of Public Administration, 1968 .

Sternlieb, George, "Abandoned Housing: Waht is to be Done?" Urban Land Vo1 31, No. 3, March 1972.

I'eska, Robert B. "Barringtons Land Bank Corporation." Landscape Architecture. June 1970.

Urban League of Khode Is Land Disinvestment in Central City Areas A position paper. September 1973.

U.S. Dept. of Housing and Urban Development. "Community Development Block Grants" Federal Kegister, Feb. 7, 1975. 
to mect its contractual obligations in an interstitc transportation authority or for motor pool nperations, may be appropristed and paid directly to such interstate transportation authority to be used by the interstatc transportation authority for its general purposes in providing a public mass transportation system within an interstate transportation district, or the city may appropriate and expend such excess funds for the purposes set forth in section $30(\mathrm{a})(2)$, of article IV, of the constitution of Missouri, as amended.

3. A city may designate by contract from line to time with an interstate transportation authority to provide specific services, frequency of service, to underwrite a certain fare structure or for any purpose consistent with providing a sound public mass transportation systen to serve the city, and the city shall appropriate and pay directly to the interstate transportation authority from the public mass transportation trust fund the amounts of money that the city finds is sufficient to enable the interstate transportation authority to perform its contractual obligations to the city, or a city may appropriatc and pay all of the funds on deposit in a public mass transportation trust fund directly to an interstate transportation authority to be used by such interstate transportation authority for its general purposes in providing a public mass transportation system within an interstate transportation district.

4. Any provision of sections 92.400 to 92.420 to the contrary notwithstanding, onc-third of the proceeds of any sales tax imposed under sections 92.400 to 92.420 that are appropriated and paid by a city to an interstate iransportation authority shall be used only by the city and the interstate transportation authority for the purchase of new equipment for the construction of public mass transportation facilities, or for any other capital expenditures or improvements to the property of the interstatc transportation authority, or to pay the interest or principal payments or to satisfy sinking fund requirements on any negotiable notes or bonds or other instruments in writing issucd by the interstate transportation authority for any of the above purposes.

5. Two-thirds of the proceeds of any sales tax imposed under sections 92.400 to 92.420 that are appropriated and paid by a city to an interstate transportation authority shall be used to supply funds to be applied to the expenses of the organization and costs of operation of the public mass transportation system and the facilities thereof, and nay be used to supply additional funds for capital expenditures as set forth in subsection 4 of this section.

(L. 1971 S. B. 147 \$10, A. L. 1973 11. B. (4))
92.420. Other payments by city to transportation authority permitted.-Nothing contained in sections 92.400 to 92.420 shall be construed to prevent a city from appropriating and paying moneys to an interstate transportation authority from any of its other revenues, and all such cities are so empowered to appropriate and pay moneys to an interstate transportation authority from any of its other revenues for any of the purposes enumerated in sections 92.400 to 92.420.

(L. 1971 S. B. 147 \& II)

Efective $6-11-71$

*92.421. Termination date, sections 92.400 to 92.420 .- The provisions of section 92.400 to 92.420 shall cxpire on September 30, 1975.

(L. 1971 S. B. 147 \$ B. A. L. 1973 H. B. $64 \$ 92.403$ )

- iransferred from 92.403.

\section{THE MUNICIPAL LAND REUTILIZATION I.AW (ST. LOUIS CITY)}

92.700. Provisions, how adopted.-All cities not within a county, which now have or may hereafter have a population in excess of five hundred thousand inhabitants, may elect by the enactment of an ordinance by the legislative body of such eity to have the collection of delinquent and back real estate taxes regulated and controlled by the provisions of sections 92.700 to 92.920 and to operate thereunder. The election to operatc under the provisions of sections 92.700 to 92.920 may be rescirided by repealing said ordinance.

(L. 1971 H. B. 472 \$)

92.705. Short title.-Sections 92.700 to 92.920 shall be known by the short title of "The Municipal Land Reutilization Law".

(L. 1971 H. B. 472 §)

92.710. Definitions.-The following words, terms and definitions, when used in sections 92.700 to 92.920 , shall have the meanings ascribed to them in this section, except where the text clcarly indicates a different meaning:

(i) "Collector", the collector of revenue of any eity operating under the provisions of sections 92.700 to 92.920 ;

(2) "Land reutilization authority", and "land reutilization commission", the authority and comnission as created by section 92.875 ;

(3) "I and taxes", general taxes on real property or real estatc and shall include the taxes both on land and the inprovements thereon;

(4) "Person", any individual, firm, copartnership, joint venture, association, corporation, estate, trust, business trust, receiver or trustee appointed by any state or federal court, trustee otherwise creat or combinatio.

(5) "School district", "spe sessment distr located totally ating under th 92.920;

(6) "Sherif and circuit cle ating under th 92.920;

(7) "Tax bil 92.920 , the rea levied and asse

(8) "Tax di: any city, muny, trict, water dis drainage distri. assessment dis within any cil of sections 92.;

(9) "Tax lic, defined in subd

(10) "Taxing or other lawfil empowered by Missouri, or at trict, road distr levee district, the provisions $\mathrm{c}$ ? (L. 1971 H. B. 472

92.715. Coll terest and costs rors, correction operating unde 92.700 to 92.9 : taxes contained ! list of the del ? collector's office

2. Any perso any tract of lan tax book or in lands and lots redeem such tra part thereof, fro thercon, by pay amount of the , interest from the of one percent $p$ of ten percent pe

3. If suit shall any tract of lant of taxes, the per land before judg, tax, interest and accruing under 
therwise created, syndicate, or any other group $r$ combination acting as a unit;

(5) "School district", "water district", "sewer istrict", "special bencfit district", "special asessment district" shall include those districts cated totally or partially within any city operting under the provisions of sections 92.700 to 2.920

(6) "Sheriff", and "circuit elerk", the sheriff nd circuit clerk, respectively, of any city operting under the provisions of sections 92.700 to 2.920

(7) "Tax bill", as used in sections 92.700 to 2.920, the real estate taxes and the lien thereof, evied and assessed by any taxing authority;

(8) "Tax district", the state of Missouri and ny city, municipality, school district, rond disrict, water district, sewer district, levee district, rainage district, special benefit district, sijecial ssessment district, or park district, located vithin any city operating under the provisions f sections 92.700 to 92.920 ;

(9) "Tax lien", the lien of any tax bill as lefined in subdivision (7) of this section;

(10) "Taxing authority", any governmental, ir other lawful authority, now or hercafter mpowered by law to issue tax bills, the state of Missouri, or any city, municipality, school disrict, road district, water district, sewer district, avee district, or drainage district, affected by he provisions of sections 92.700 to 92.920 .

- 1971 H. ४. 472 §3)

92.715. Collectors to act-redemption, inrest and costs-compromise of judgment-erors, correction of.-1. The collectors of cities perating under the provisions of sections 2.700 to 92.920 shall proceed to collect the axes contained in the back tax book or record st of the delinquent land and lots in the ollector's office as herein required.

2. Any person interested in or the owner of iy tract of land or lot contained in the hack $x$ book or in the recorded list of delinquent nds and lots in the collector's oflice may 'deem such tract of land or town lot, or any tri thercuf, from the state's or such city"s licn iercon, by paying to the proper collector the nount of the original taxes, togetle:r with terest from the date of delunquency at the rate one percent per month with a maximum rate ten percent per ammum and the costs.

3. If suit shall have heen commenenced agatinst by tract of land of lowen hol for the collection taxes, the persons desiring to redeen any such ad before julgnent, in aldition to the original $x$, interesi and costs including : alformeves tece

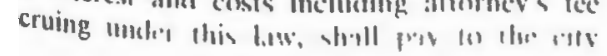

collector all necessary costs incurred in the court where the suit is nending, and the city collector shall account to the clcrk of the court in which said suit is filed for the court costs so collected.

4. The provisions of the law with reference to the compromise of taxes shown on the back tax book or recorded list of delinquent land and lots in the collector's office shall apply to and shall also authorize the compromise of any judgment for taxes after the same had been rendered therefor and up to that time when the property shall be sold under exccution issued on said judgment; such compromise to be authorized by the same officials and under the same conditions as set forth under existing law for the compromise of taxes. The comptroller of any city operating under the provisions of sections 92.700 to 92.920 sluall serve in lieu of the county court. The comptroller shall also have the right to correct manifest errors.

(L. 1971 H. B. $472 \$ 4)$

92.720. Unredecmed lands, how proceeded against, lists-limitation on actions.-1. If any of the lands or town lots contained in the back tax book or list of delinquent lands or lots remain unredeemed on the first day of January, the collector may file suit in the circuit court against such lands or lots to enforce the lien of the state and city as herein provided in sections 92.700 to 92.920 .

2. The collector shall note opposite such tract in the back tax book the fact that suit has been commenced.

3. The collector shall compile lists of all state, city, school and other tax bills collectible by him which are delinquent according to his records and he shall assign a serial number to each parcel of real estate in each list and if suit has becn filed in the circuit court of the city on any delinquent tax bill included in any list. the collector shall give the court dexchet mumler of each suit.

4. The sheriff may appuint the collector and the collector's deputies as deputy sherifls, amol when so apprinted they may serve all process in

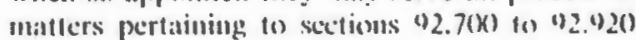
with like effect as the sherift himsell miglt sk.

5. No antion for reerery of taxes against real estate shatl be commenced, had or matintamed, unless action therefor shall be commeneed within tive years after kelinquency.

(1.. I47) 11 B. 47? \$ \$)

92.725. Lists, contents of.--Each list shall contain the following:

(1) A description of the land by the smallest legal subdivisions of by llac vmallest pallts, hess. 
or pareels whell sections and subdivisions thereof are divided into lats, blocks or pareels, and when such real estate cannot be so diescribed, then by metes and bounds: and variance in any dexcription of such real estatc from year to year or any such variance hetween taxing authorities shall not be matcrial so long as such descriptions reasonably identify the same land;

(2) A statement of the amount of each tax bill upon such parcel, including all tax bills thereon which are delinquent, the year of such assessment, the tritet number, if any, of each tax bill, and the date or dates from which and* the rate or rates at which interest and penalties shall be computed, and an appropriate designation of the owner or holder of cach such tax bill;

(3) The name of the last known person appearing on the records of the collector in whose nane the tax bills on such real estate were listed or charged for the year preceding the calendar year in which such list is filed.

(1.. 1971 11. 13 $472 \$ 6$ )

" Hurd "ond" apprars in original rolls.

92.730. Consolidation of pending suritscosts to be lien-defenses preserved.-1, All suits to collect delinquent tax bills which may be pending at the time of the commencement of any suits brought under the provisions of sections 92.700 to 92.920 affecting the same land shall be consolidated with suits brought under said sections, and the parties to such pending suits shall tile answers within the time and as provided in sections 92.700 to 92.920 , but any tax bills sought to be collected in any pending suits may be included in any list or lists included as a part of any petition filed by the collector and, if so included in any list filed as part of any such petition, sucli inclusion shall act as an abatencent of any such pending suit, and all amounts then duc on such tax bills, including interest, penalties, attorn.y's fees and costs, shall be so listed and charger, and shall thereupon continue in full force and eflect the liens therefor against the respective parcels of real estate described therein and so listed in the petition filed under the provisions of sections 92.700 to 92.920 ; and, when so listed and included in the petition, no answer shall be required to be filed in such collector's suit to collect such delinquent bills.

2. Suits brought under the provisions of seetions 92.700 to 92.920 , involving delinquent tax bills sought to be collected by suits pending at the time suits are brought under sections 92.700 to 92.920 , shall be tried als all wher actions under said sections, and the statutes of limitations shall not prevent the parties to such pending suits from asserting all rights and dofenses which they then lad.

\section{(1 [47! 11, 1 $472 \leqslant 7)$}

92.735. Joinder of parcels, how numbered. fec.- - Aly number of pareels of real eistate may be joined in onc petition or suit. Each separate tract or parcel of real estate joined in any onc action shall be given a serial number by the collector and slaall be separately indexed and docketed by the cireuit clerk in a book kept by the clerk for that purpose. lior eacli scrially numbered pareel of real estate, the circuit clerk shill be allowed a fec of ten cents, which shall be taxed and paid as other costs in the case which he shall pay into the eity treasury in accordance with the provisions of chapter 82 , RSMo.

(I.. 1971 H. B. 472 \& B)

92.740. Petition, form, contents.--1. A suit for the foreclosure of the tax liens herein provided for shall be instituted by filing in the appropriate office of the circuit clerk and with the land reutilization authority a petition, which petition shall contain a caption, a copy of the list prepared by the collector, and a prayer. Such petition without further allegation shall be deened to be sufficient.

2. The caption shall be in the following form: In the Circuit Court of _______ Missouri, In the Matter of

Foreclosurc of Liens for Delinquent Land Taxes By Action in Kem. Collector of Revenuc of . Missouri, Plaintif

Parcels of Land Encumbered with Delinquent Tax Liens, Defendants

3. The petition shall conclude with a prayer that all tax liens upon such real estate be foreclosed; that the court determine the amounts and priorities of all tax bills, together with interest, penalties, costs, and attorney's fees; that the court order such real estate to be sold by the sheriff at public sale as provided by sections 92.700 to 92.920 and that thereafter a report of such sale be made by the sheriff to the court for further proceedings under the provisions of sections 92.700 to 92.920 .

4. The petition when so filed shall have the same force and effect with respect to each parcel of real estatc therein described as a separate suit instituted to foreclose the tax lien or liens against any one of said parcels of real estate. (L. 1971 H. B. 472 §ु 9)

92.745. Action in rem, pleadings, failure to answer, effect of.-1. The foregoing proceeding or suit shall constitute an action in rem, and the pleadings therein shall consist of a petition and an answer or ansivers.

2. An answer may be filed by any person or tuxing authority owning or claiming any right, 
interest in or to any tax bill (omstituting en on the real estate descolled in the , or by any person owning of clatiming it, title, or interest in or to, or licn upons, al estate. An answer shall include the and amount of the interest and any or sbjection to the foreclosure of the tax tea in the prition, and may inchele the ms usually incorporated in pleadings cross-putitions, cross-complaints, inter. $r$ intervening petition.

II pleadings must he brief, clear and , and shall be liberally constumed by the Any such answer shall contain the capid number of the case, and the serial - or numbers of the parcels of real cstate icd. Such answer must be filed with the clert: and a copy thereof served on the is not later than sixty calendar days after $e$ of the first publication of the notice of iure, and if such sixtieth day falls on a or legal holiday. then such answer may on the day after such Sunday or legal

the cuent of failure to answer within the erein fixcd, a default judgment may be s to all tax bills affecting parcels of real s to which no answer has been filod.

H. H. $472 \S 10)$

50. Redcmption by intercstcd party, ate-foreclosure sale, effect of.--!. Any having any right. title or interest in, or on, any parcel of real estate described in etition may redeem such pareel of real oy paying to the collector all of the sums ned therein, includiing principal, interest, es, attorney's fees and costs then due, at ne prior to the time of the foreclosure such real estate by the sineriff.

the cuent of failure to redecm prior 10 ne of the foreclostre sate by the sheriff, erson shall be barred and foreser foreof all his righe, tithe and interest in and parcels of real estate deseritud in such

Jpon redemprion. as permitted by this , the persenn redecming shall be entitled rtificate of redemption from the collector ing the preperty in the satme manner as it ribed in such petition, and hle collector hereupon note on his cecords the word

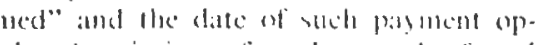
the description of stich parced of real

11. 11. $47 ? \$ 111$

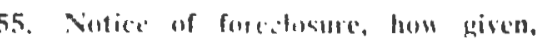

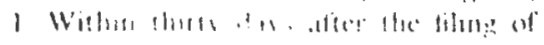

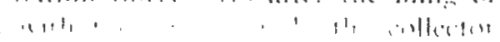

shall forthwith caune a notice of foreclosure to be publisbed fous times. once a week, during successive weeks. and (nt the same day of each week, in at daity newspaper of peneral circulattion regulaty published in stech city, yualified according to law for the publication of public notices and adverisements

2. Such notice shall be in substantially the fillowing form:

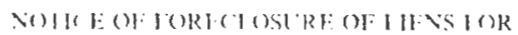

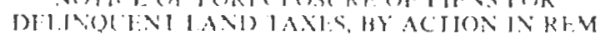

public nutice is herebs given that on the day of 19), toe colleven of Revente of

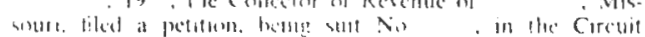

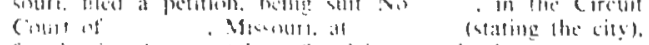

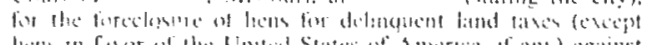

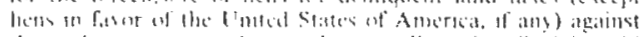

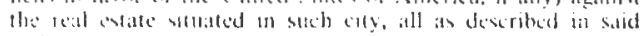
pe'lituris.

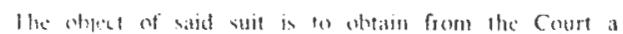

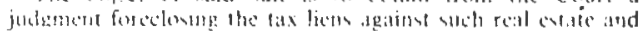

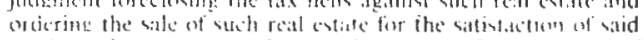

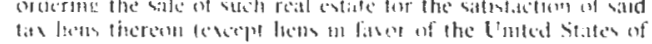

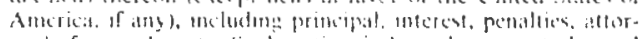
nes fere and conf such action is trought agamal the real

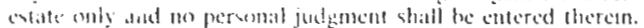

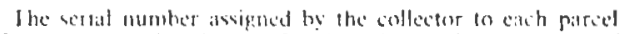

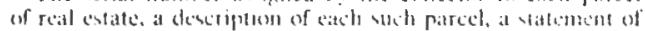

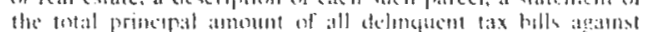
cich such patrect of real estate. all of which, as to sth natuct.

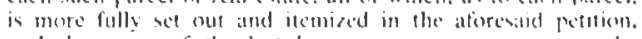

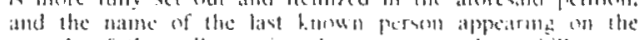
recerds of the colfector in whowe nime sals tat hill, sere listed or charged for the year preceding the calcoldar ye an which the list deseribed in satd pertion wats filed with the collector, are, respectisedy, as follems:

(llere set out the respective setial numbers, descriptions, names and statcments of tolal promeipal amounts ni tar hills, next ahove referred 6 .)

The tstal principal amounts of devinguent taxes set out in

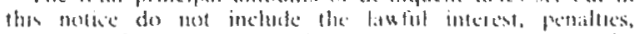

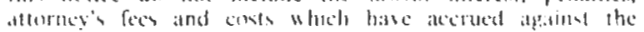
respretise pircels af real entate, all of which in cach ease is set

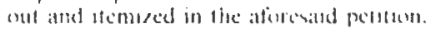

Any persm or tavise anthoilf ownthe or holdting any tax

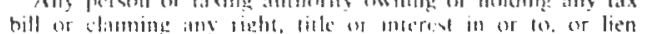

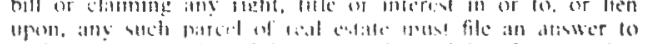

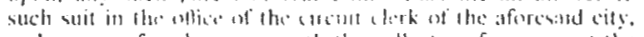
atnd a copy of smbl ambuer wh the collector of resemme at the

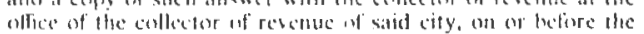

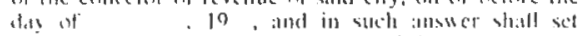
forth in detid the patule and ameunt of stleh interest ant any

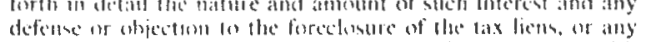

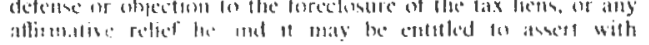

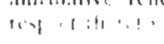

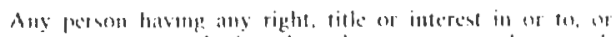

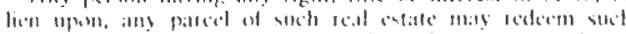

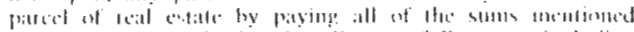

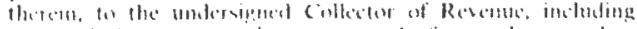

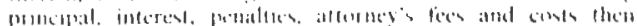

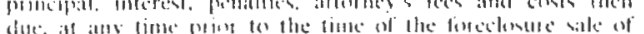

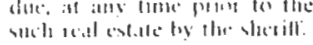

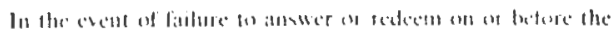

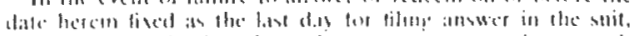

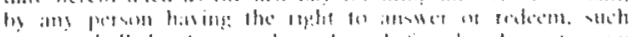

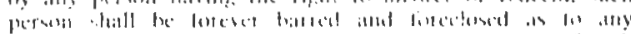

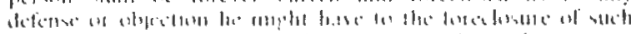

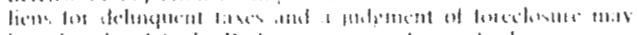

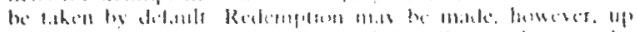

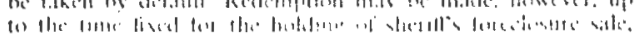

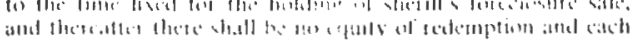

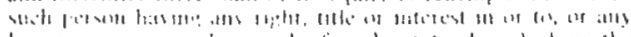

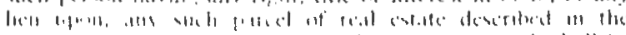

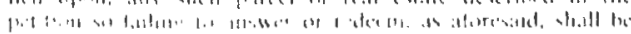

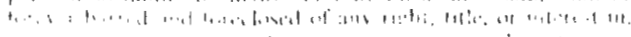

$$
\text { , ill it } 1,1+1,1,1,1
$$




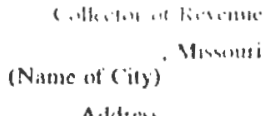

Addicis

Altorncy

Addicas

First Publication

(1. $197111,11.172 \div 12)$

92.760. Notice of filing, how mude, form of -1. The collector shatl also calse to be prepared and mailed in an envelope: with postinge prepaid, within thirty days after the filing of such petition, a briet notice of the tiling of the suin, wo the persoms named in the petition as being the fast hiluwn persoms in whose names tax bills affecting the respective parcels of real estate described in said petition were last billed or charged on the books of the collector, and to the andresses of sadd persons upon said records of the eollector; and in the event that any name or adciess does not appear on the records of the collestor, with respect to any parcel of real estatc, the collector shall so state in an attidavit, giving the serial number of exch pares of real estate allected. Said atlidavit shatl be filed in the suit with the cireuit clerk not later than sixty diys after the dite of the first publication of the notice of foreclosure. The lailure of the collector to mail the notice or lile the atfidavit herein providicd shall nut affiec the validity of any proceedings brought purstiant to the provisions of sections 92.700 to 92.920 .

2. Such notice shall be substantially as follows:

To the prerson to whom this notice is athesesed fou atre the las known nerson. deconding to the records in the office.

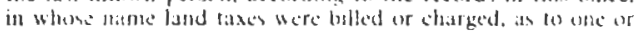

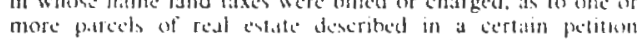

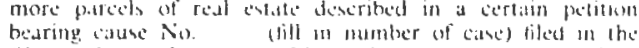

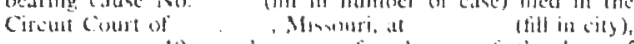

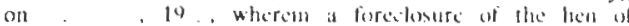

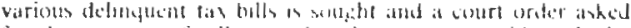

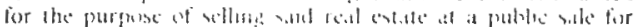

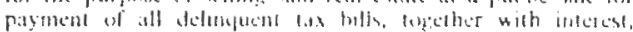

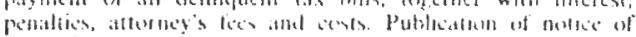

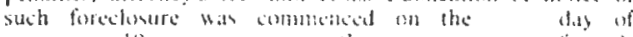

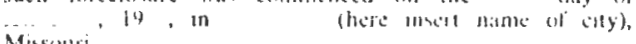

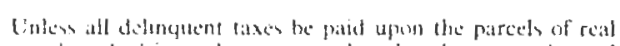

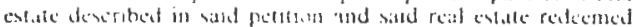

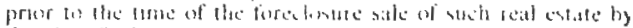

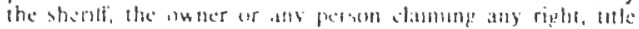

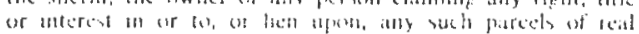

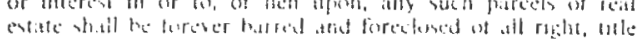

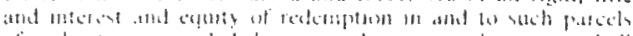

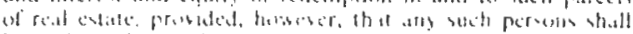

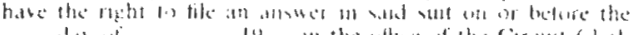

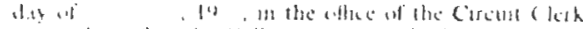

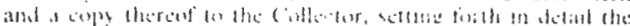

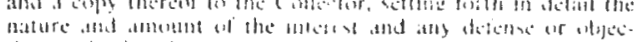
(iin) bis the fincelware.

Ditid
(1. 1971111347.9511 .44$)$

92.765. Records of artions tinken, where

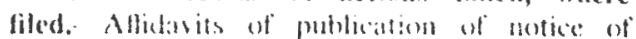

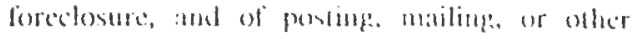

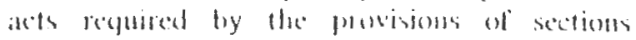

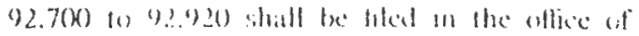
the cineuil reok prose to the trial, and when so filed shall comstume past of the evidentiary

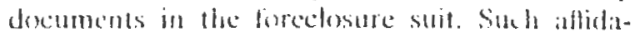
wits slutl lo prima lacie evidemes of the performance of atels therein describel, and maty he so used in the wial of the suit, matess ehallengerl by verified answer duly lifed in the suit.

(1.. 1971 11. 13. $472 \$ 15)$

92.770. Attorncys, cmployment anthorized, compensation.- 1 . The collector mat cmploy such attorneys as the decms necessary to collect such taxes and to prosecute suits for taxes.

2. Such attorneys shall receive as total compensation a sum, not to exceed six percent of the amount of taxes actually collected and paid into the trasury, and an additional sum not to exceed two dollars for eich suit biled when publication is not necessary and not to exceed five dollars where publication is necessary, as may be agreed upon in writing and approved by the collector, beforc such services are rendered.

3. The attorney fees shall be taxed as costs in the suit and collected as other costs.

(L. 1971 H. H. 472 \$ 16$)$

92.775. Trial, evidence, judgnent-severances-jury nut authorized-precedence of action.--1. Upon the trial of the causi upon the guestion of forculosure, the tax bill shall be prima tacic profof that the tax described in the tax bill has been validly assessed at the time indicated by the tax bill and that the tax is unpaid. Any person alleging any jurisdictional defect on invalidity in the tax bill or in the sale thereot must particularly specify in his answer the defect or baths of imalidity, and must, upon trial, afirmatively establish such defense.

2. Alter the court has first determined the validity of the tax liens of all tax bills affecting parecls of real estate described in the petition, the promities of the respestive tax bills and the anomos de thereon, including principal, interest, penalites, attormey's fees, and costs, the court shall thereupon ciller jublement of toredosure of such liens and the the tine and place of the forcensuse sole. I the perition stall be dismisuced an an any parcel of real estate reticered prior to the rone tixed lin the sheritrs forcelo. sure sake an provided in sections 92.700 to 92.920. If the pareel of real estale auctioned of 
with the eircuit elerk, the sheriff shall commence to advertise the real estate described in the judgment and shall fix the date of sale within thirty days alter the diate of the tirst publication of the notice of sherifts salc as herein provided, and shall at such sale proceed to sell the real estate.

\section{(L. 1971 HI. B 472 \$21)}

92.815. Redemption contracts, installment payments.-I. During such waiting period and at any time prior to the time of foreclosure sale by the slicrift, any interested party may redeem any pareel of real estate as provided by sections $\mathbf{9 2 . 7 0 0}$ to 92.920 ; provided, however, that during such time and at any time prior to the time of foreclosure sale by the sheriff, the collector may enter into a written redemption contract with any such party interested in any parcel of real estate providing for paynient in installments, monthly or bimontlily, of the delinquent tax bills, including interest, penalties, attorney's fees and costs charged against such parcel of real estate, provided, however, that in no instance shall such installments exceed twelve in number or extend more than twenty-four months next after any agreenent for such installment payments shall have beell entered into; provided further, that upon good cause being shown by the owner of any parcel of real estate occupied as a homestead, or in the case of improved real estate with a total assessed valuation of not more than five thousand dollars, owned by an individual, the inconse from such property being a major factor in the total income of such individual, or by anyone on his behalf, the court may, in its discretion, fix the time and terms of payment in such contrac! to pernit all of such installments to be paid within not longer than forty eight months after any order or agreement ats to installment paynients shall have been made.

2. So long as such installments be paid according to the terms of the contract, the said six months' waiting period shall be extended, but if any installment be not paid when duc, the extension of said waiting period shall be encled without notice, and the real estate shall forthwith be alvertised for sale or included in the next notice of sheriff's foreclosure sale.

(L. 1971 H. H. 472 \$20)

92.820. Sale, where held-notice, form of.1. At the front door of the courthouse of the city of _ a at which sales of real estate are customarily made by the sherift under execution, the sheriff shall advertise by posting the notice tor sale and sell the respective parcels of real estate ordered sold by him pursuant to any judgnent of foreclosure by any court under the provisions of sections 92.700 lo 92.920 .
2. Such advertisements by posing of notice of sale may include more than one parcel of real estate, and shall be in substantially the following form:

NOTICI: OF SHERIFF'S SALE UNDER JUDGMENT OF IOTRLCLOSURE OF: I.II:NS FOOR DELINQUENT I.AND TAXLS

In the Circuit Court of

In the Matter of Foreclosure of Iiens

for Delinquent Land Tuxes

Collector of Revenue of _____ Missouri,

Plaintif,

-vsNo.

Parcels of Land encumbered with Delinquent Tax Liens, Defendants.

WII:R FAS, judgment has been rendered against parcels of real estate for taxes, interest, penaltits, attorney's fees and costs with the serial numbers of each parcel of real cstate, the destription thereof, the name of the person appearing in the petition in this sult against whom the tax bill was fisted or charged, and the total amount of the judgment against each such parcel for taxes. interest, penalities, altorncy's fees and costs, all ats set sut in said judgment and dexcribed in each case, respectively, as follows:

(Here set out the respective serial numbers, descriptions, nimes and total amounts of each judgment, nexi above referred to.) and,

WHEREAS, such judgment orders such real estatc sold by the undersigned sheriff, to satisfy the total amount of such judgment, including interest, penalties, atturney's fees and costs,

NOW, THEREFORE,

Public: Notice is hereby given that I, Sherift of Missuuri, will sell such real estate, parcel by parcel, at nublic auction. to the highest bidder, for cash, between the hours of nille o'clock a.m. and five o'clock p.m., at the

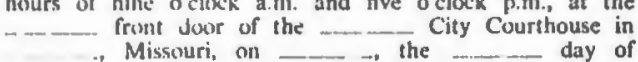

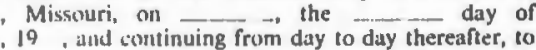
sutisfy the judgment as to eath respective parcel of real estate soiel. If no acieptable bids are received as to any parcel of real estate, said partel shall he sold to the Land Reutilization Authority of .... - Missouri.

Any bid received shall be subject in confirmation by the Court.

Sheriff of Missouri

First Publication 19

(L. $197 !$ H. 1). $472 \$ 22$ )

92.825. Sale, how conducted-interest conveyed-costs, advanced how.-1. The sale shall be conducted, the sheriff's return thereof made, and the sherifrs deed pursuant to the sale exccuted, all ats provided in the case of sales of real estate taken under execution except as otherwise provided in sections 92.700 t, 92.920 , and provided that such sale need not occur during the term of court or while the court is in session.

2. Such sale shall convey the whole interest of every person having or claiming any right, title or interest in or licn upon such real estate, whether such person has answered or not, subject to rights-of-way thereen of puhlic utilities upon which lax has been otherwise paid, and 
the parcels of real estate described in the notice of sherifts foreclosure sale. At the time of such hearing. the sheriff shall make report of the salc. and the court shall hear evidence of the value of the property offered on behalf of any inierested party to the suit, and shall forilswitl deternine whether an adequate consideration has been paid for cach such parcel.

2. For this purpose the court shall have power to summon any city official or any private person to testify as to the reasonable value of the property, and if the court finds that adequate consideration has been paid, he shall confirm the sile and order the sheriff to issue at deed to the purchaser. If the court finds that the consideration paid is inadequate, the purcliaser may increase his bid to such amount as the court may deen to be adequate, whereupon the court maly confirm the sale. If, however, the purchaser declines to increase his bid and make such additional payment, then the sale shall be disapproved, the lien of the judgment continued, and such parcel of real estate shall be again advertised and offered for sale by the sheriff to the highest bidder at public auction for cash at any subsequent sherifts foreclosure sale.

3. If the sale is confirmed, the court shall order the proceeds of the sale applied in the following order:

(1) To the payment of the costs of the publication of the notice of foreclosure and of the sheriff's foreclosure sale;

(2) To the payment of all costs including appraiser's fee and attorney's fees;

(3) To the payment of all tax bills adjudged to be due in the order of their priority, including principal, interest and penalties thereon. If, after such payment, there is any sum remaining of the proceeds of the sheriff's foreclosure sale, the court shall thereupon try and determine the other issues in the suit in accordance with section 92.775. If any answering parties have specially appealed as provided in section 92.845 , the court shall retain the custody of such funds pending disposition of such appeal, and upon disposition of such appeal shall make such distribution. If there are not sufficient proceeds of the salc to pay all claims in any class described, the court shall order the same to be p:id pro rata in accordance with the priorities.

4. If there are any funds remaining of the proceeds after the sheriff's sisle and after the distribution of such funds as herein set out and no person entitled to any such funds, whether or not a party to the suit, shall, within two years after such sale, appear and claim the funds, they shall escheat to the state as provided by law.

(L. 1571 H. B. 472 \$26)
92.845. Appeals,-The collector or any inieresled person or anyone on belialf of any inconinetent may appeal from the judgment confirming or disapproving the sheriffs sale and the distribution made thereafter; provided, however, no question can be raised upon such appeal that could have been raised upon an appeal from the judgment of foreclosure. Such appeals must be taken within twenty days after the date of such judgment. The necessity for giving bond and the provisions thereof shall be the same as in cases of appeal fron a judgment of foreclosure.

(L. 1971 H. B. 472 \& 27)

92.850. Deputy sheriff, authority.-Any lawfully appointed deputy sheriff may perform all acts and things herein required to be done by the sheriff, including the conduct of any sales, reports of such sales and the issuance of deeds according to the order of the court, in the name of and with like effect as the sheriff himself might do.

(L. 1971 H. B. $472 \$ 28$ )

92.855. Sheriff's deed, effect of.-Each sheriffs deed given pursuant to the provisions of the municipal land reutilization law shall be presumptive evidence that the suit and all proceedings therein and all proceedings prior thereto from and including assessment of the lands affected thereby and all notices required by law wcre regular and in accordance with all provisions of the law relating thereto. After two years from the date of the recording of such sheriffs decd, the presumption shall be conclusive, unless at the time that this section takes effect the two-year period since the recording of such sheriffs deed has expired, or less than six months of such period of two years remains unexpired, in which latter case the presumption shall become conciusive six months after September 28, 1971. No suit to set aside or to attack the validity of any such sheriffs deed shall be commenced or maintained unless the suit is filed prior to the tirnc that the presumption becomes conclusive, as aforesaid.

(L. 1971 H. B. 472 \$29)

92.860. Fees allowable.-1. Fees shall be allowed for services rendered under the provisions of sectious 92.700 to 92.920 , as follows:

(1) To the collector, two percent on all sums collected and twenty-five cents per tract for making the back tax books;

(2) To the circuit clerk, sheriff and printer, such fees as are allowed by law for like services in civil cases.

2. Such fees shall be taxed as costs and cullected from the person redeeming such tract or from the proceeds of sale. 


\section{U. B. $472 \S 30)$}

53. Costs, how apportioned-collector's 1. All costs, including costs of publishing tices, and any court costs, shall be apporamong the respective taxing authorities o rata basis.

any party redecms any pareel of real from the lien of any tax bill, such party $\mathrm{n}$ addition to all other anounts then due, ng principal, interest, attorney's fees and also pay costs to the collector as follows:

Fifty cents per parcel of real cstate for c of certificate of redemption;

One dollar per parcel of real estate, if of publication has been commenced;

In additional one dollar per parcel of real if notice of sheriff's foreclosure sale hats mmenced.

H. B. 472 \$31)

65. Amended petition, when allowed.option of the taxing authority or tax bill all claims for land taxes against any of real cstate, which has been included in etition filed under sections 92.700 to where such taxes have become due and after any tax list or petition thereon has ed, may be asserted by amended petition answer filed before judgment, and, if by the court, shall be included in the nt against such parcel of real estate.

\section{H. B. $472 \S 32$ )}

10. Applicable provisions of general law y.-The general law relating to taxation e collection of delinquent taxes as now : and the provisions found in sections to 92.920 shall apply to cities not within inty and which now have or may hereafc a population in excess of five hundred id, insofar as not inconsistent with the uns of sections 92.700 to 92.920 .

II. B. 472 \$33)

5. Iand reutilization authority created, - - 1 . There is hercby crented an authorthe management, salc, trans $\int e r$ and other ion of tax delinquent lands, which aushall be known ass "The I.and Reutilizasthority of the city of _.__... MisIt shall have uuthority to accept the fany interest in real property made to it, ccept gifts and grant in aid ascistance. sthority shall have and exercise all the conferred by the provisions of sections (1) 12.920 necessatry and incidental to the - manalyement, sale, transter or other oun of real estatc acquired under and by of the fincelosure of the lien for delin- quent real estate taxes, as provided in sections 92.700 to 92.920 , and in the excrcise of such powers, the land reutilization authority shall be deened to be a public corporation acting in ? governmental capacity.

2. The land reutilization authority is hereby created to foster the public purpose of returning land which is in a nonrevenue generating nontax producing status, to effective utilization in order to provide housing, new industry, and jobs for the citizens of any city operating under the provisions of sections 92.700 to 92.920 and new tax revenues for said city.

(L. 1971 H. B. 472 \$ 34)

92.880. Beneficiaries of authority-interest, how determined.- The beneficiaries of the land reutilization authority shall be the taxing authorities which held or owned tax bills against the respective parcel of real estate sold to the land reutilization authority at sheriffs foreclosure sale included in the judgment of the court, and their respectiv: interests in each parcel of real estate shall be to the extent and in the proportion and according to the prioritics determined by the court on the basis which the principal anount of their respective tax bills bore to the total principal amount of all of the tax bills described in the judgment.

(L. 1971 H. B. 472 \$ 35)

92.885. Members, appointment-vacancy, how filled.-1. The land reutilization authority shall be composed of three members, one of whom shall bc appointed by the comptroller of any city operating under the provisions of sections 92.700 to 92.920 , one of whom shall be appointed by the board of education of such city, and one shall be appointed by the mayor of any such city. The menbers shall serve at the pleasure of their respective appointing authority and shall scrve without compensation. The members so appointed may be employees of the appointing authority and shall serve without additional compensation.

2. Any vacancy in the office of land reutilization commissioner shall be filled by the same appointing authority which made the original appointment. If any appointing authority fails to make any appointment of a land reutilization commissioner within the time the first appointments are required, or within thirty days after any term expires, then the appointnent shall be made by the mayor of the city.

(1. (1)71 H. 13. 472 §. 36)

92.890. Commissioners, organizution, bond, oath. -1 . Such land reutilization conmissioners shall meet ininuediately after all three have been 
appointed and qualified and shatl select a chairmant, a vece chairman and a secretary.

2 finch conmissiomers stall each furnish at surety hond, if such boust is not already covered by goverumentisl surety bond in a penal sum not to exeed twenty-five thousand dollars to be approved by the comptroller, the premitum of such bond to be paid by tlie coniptroller out of the eity funcls. Such bond must be issued by a surety company licensed to do business in the state of Missouri, and shatl be conditioned Io guarantec the faithful pertormance of their duties hereunder, and shall be written to cover all the eomnissioners.

3. Before entering upon the dulies of his oflice, each commissioner slaall take and subscribe to the following oath:

Stalc of Missuri

Ciiy of

I. do silenunly swear that I will support the Constitution of the United States, and the Constitution of the state of Missuriti: that I will faithfully and impartially discharue my dutics as a member of the l.and Reutilization charge my duties as a member of the land Reutilizition
Authority of Authority of
best knut ledge and judgment, administer such tax definquent lands held by me in Irust, dicurding to the laws of this state and for the benetit of the public hodies and the tax bill owiser which 1 repiesent, so help me ciod.

Subseribed and sworn in this day of $\quad, 19$

M) commission expires:

Notiars Püblic

\section{(L. 1971 H. B. 472 \$ 37$)$}

92.395. Authority's seal, powers,-1. Such land reutilization authority shall be a continuing body and shall have and adopt an oflicial seal which shall bear on its face the words "Land Reutilization Authority of "Missouri", "Seal", and shiall have the power to sue and issue deeds in its name, which deed shall be signed by the chairman or vice chairman, and attested by the secretary or assistant secretary and the ofticial seal of the land reutilization authority affixed thereon, and shall have the general power to administer its business as any other corporate body.

2. The land reutilization authority may convey title to any real estate sold or conveyed by it by general or special warranty deed, and may convey as absolute tille in fee simple, without in any case procuring any consent, conveyance or other instrument trom the bencticiaries for which it acts; provided, however, that each such deed shall recite whether the selling price repressents a consideration equal to or in excess of two-thirds of the appraised value of such real estate so sold or conveyed, ancl if such scllung price represents a comsideration less than twothicds of the appraised value of said real estate, flen the land reutilizatuen commissioners shall first procure the consent therelo of not less th.an two of the threc appointing authoritics, which consent shall tee evidenced by a enpy of the action of each such appointing aluthority duly certificel to by its clerk or secretary attached to ancl made a part of said decl.

(L. 1971 II. 1. $472 \$ 38$ )

92.900. Duties of authority. - It shall be the duty of such land reutilization authority to administer the tax delinquent lands, as follows:

(1) Such land reutilization authority shall immediatcly assume pussession and control of all real estate acquired by it under the provisions of sections 92.700 to 92.920 and proceed to inventory and appraise such land, and thereafter keep and maintain a perpetual inventory of such real estate, except that individual parcels may be consolidated and grouped or regrouped for cconomy, utility or convenience.

(2) It shall classify such land as to its use, into the following three classifications:

(a) Suitable for private use;

(b) Suitable for use by a public agency;

(c) Not usable in its present condition or situation and held as a public land reserve.

Any parecl of property may be reclassified by two-thirds vote of the land reutilization commissioners.

(3) Such land reutilization authority shall administer all property in classification (a) of subdivision (2) in accordance with subdivision (4) of this section. Every effort shall be made to sell said property at a price as close to its appraised value as possible. Property in classifications (b) and (c) of subdivision (2) may be transferred at no cost, except any administrative expenses connected with said transfer, by said land reutilization authority upon request of and to those public agencies provided for in classification (b) of subdivision (2) upon submission of a plan of use for said property by said public agency to the land reutilization commissioners, except that too property shall be transferred at no cost unless there be a unanimous vote of the three land reutilization commissioners. If said property is transferred at no cost to any public agency and suid public agency shall then sell or otherwise dispose of said property within ten years for any consideration, the procecds of said sale or disposial shall be returned to the land reutulization commissioners who shall in turn distribute said proceeds in accurdance with the provisions of section 92.8.40. If said land reutilization conmuissioners do not give an allirmative vote to said request for transfer, the land reutilization anthority may dispose of sisici property in accordance with subdivision (4) of this scetion. 
ies in classification (c) of subdivision (2) e studied and recomnendations made to authorities as to possible uses for real in said classification. In furtherance of ect such land seutilization authority shall ccess to any and all city and county at any time and may call upon any and and county officers, departments, boards, g conmmissions or other commissions for sta:istics or recommendations. Such utilization authority shall prepare a list and in class (a) of subdivision (2), which 11 be corrected and amended from time in the discretion of the commissioners. ommissioners inay make a charge, not to one dollar for each copy of such list. money shall be used to help defray the $f$ preparing such list. Any person may ie a copy of such list. Any real estate or broker licensed to do business in the y when authorized by the comnissioners y such property upon the terms and ons imposed by the commissioners. and nmissioners are authorized and cmpowpay a reasonable real cstate commission; zvided, that nothing herein shall prohibit nmissioners from selling or exchanging ch real estate direetly to or with any ser.

Such land reutilization commissioners ave power, and it shall be their duty, to , maintain, protect, rent, lease, rcpair, alter, sell, tradc, exchange or otherwise of any such real estate, on such terms inditions as may be determined in the sole on of the commissioners. Such land :euon commissioners may assemble tracts or of real estate for public parks or other purposes and to such end may exchange and otherwise effectuate such purposes ement with any taxing authority.

Such land reutilization authority shatl ules and regulations in harmony with the ons of sections 92.700 to 92.920 and shall cords of all its transactions, which recall be (upen 10 inspection of any taxing ty in the eity at any time. There shall be unal audit of the affairs, acconnts, exand financial transactions of such land ation authority by certified public acint as of Decenber thirty-first of each which accountants shall be employed by nenissioners on or before Plovember first year, and certified copies thereof shall vished to the apprinting atuhorities dein sectem 02.885 and shall be available blic inspection at the ofliecs of such tung authorities.

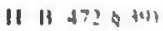

15. Dirretur and employenes, appoint. ment-funds, how obtained, deposit of, anditsexpenditures, how nadc.- 1 . The land reutilization commissioners may apprint a director and such other employees who are deened necessary (o) carry out the responsibilities and duties herein imposed and may incur such other reasonable and proper costs and expenses as are related thereto. If such costs and expenses exceed the amount of funds avisilable to the land reutilization authorify under provisions of sections 92.700 to 92.920 , the land reutilization authority shall obtain approval of the board of estimate and apportionment and an appropriation by the governing body of the eity for such additional or supplenental fund needs. Such appropriations by the city shall be considered advances io the land reutilization authority subject to repayment from finds supplementally accumulated by the land reutilization authority under provisions of law.

2. The comptroller of the eity shall handle al! such appropriated expense funds and disburse sanne under the same provisions for handling other city departınental expenditures.

3. The land reutilization: authority shall deposit all funds received under provisions of sections 92.700 to 92.920 with the treasurer of the city, and the comptroller of the city sliall maintain scparate fund accounts for such deposits and nake disbursements therefrom upon receipt of vouchers duly authorized by the land reutilization authority under provisions of sections 92.700 to 92.920 and in accordance with standard procedures adopted by and approved by the comptroller.

4. The fiscal year of the land reutilization authority shall commence on January first of each year. The land reutilization authority shall audit all claims for the expenditure of money, and shall, acting by the chairman or vice chairman thereof, draw warrants therefor from time to time.

(1.. 1971 II. B. $472 \S 40$ )

92.910. Inventory of real cstate required.The land reutilization anthority siall set up and maintain a perpetual inventory on each tract of its real estatc, except that individual tracts may be consolidated and grouped or regrouped for econonyy or eouvenience.

(L. 1971 II. 13. $472 \$ 411$

92.915. Accounts, how kept-expenditures, priority of.-1. The land reutilization anthority shall set up accounts sm its books relating to the operation, mantigement, or other expense of each indiviclual prirect of real estatte.

2. When any iareel of real estatc is sold or otherwise dispessed of by the land reutilization 
authority, the proceeds therefrom shall be upplied and distributed in the following order, except as provided for in section 92.900 :

(1) To the payment of the expenses of sale, the costs of the care, improvement, operation, demolition, management, and administration of such parcels of real cstate as determined by the land reutilization commissioners and apportioned to such parcel;

(2) To the payment of any penalties, attorney's fees or costs which were included in the judgnent originally entered against said parcel of real estate, plus its proportional part of the costs of sherifts foreclosure sale, as shown on the books of the collector;

(3) The balance to be paid to the respective taxing authorities and tax bill owners, if any, in the proportion that the principal amounts of the tax bills of each such party tears to the total principal amount of all the tax bills included in the original judgment relating to such parcel of real estate and in the order of their respective priorities.

After deduction of all sums charged to each account for various expenses, destribution shall be made to the respective taxing authorities and to tax bill owners having an interest in such parcel of real estate, on January first and July first of each year, and at such other tines as the land reutilization commissioners in their discrelion may determine.

(L. 1971 H. B. 472 \$ 42)

92.920. Members and employces prohibited from profiting from operations of authority, exeeption-penalty.-1. Neither said members nor any salaried employee of the land reutilization authority provided for herein shall receive any compensation, emolument or other profit directly or indirectly from the rental, management, purchase, sale or other disposition of any lands held by such land reutilization authority other than the salaries, expenses and emoluments provided for herein.

2. Any person convicted of violating this sectiori shall be deemed guilty of a felony and upon conviction thereof shall be sentenced to serve not less than two nor more than five years in the state penitentiary.

(L. 1971 H. B. $472 \$ 43$ ) 


\section{6-II ' 601}

Introduced by-

Thepresontalives Magrgiacomo and Manning

Orcäcel I'rinted by-

Ifouse ol hepresentatives

Referred to-

Honse Committeo on Judiciary

Date Printed-

March 19, 1976

State of IRliode Island and Providence Plantations

JANUARY SESSION, A. D. 1976

AIN DCT Eielating to Abandoned Property and tho Homestead Program.

It is enacted by tha General Assembly as follows:

Section 1. Chapter 9 of title 44 of the gencral laws as anended entitled "Tax sales" is hereby further amended by adding thereto the following sections:

44-9-25.1. FOIRCLOSURY OF THE RIGYTS OF. REDEMIPTION ON ACCOUNT OF AEA RTDONTLENT. - Notwithstanding the provisions of section 44-9-25 of this chapter, following a sale of land for taxes, whoever then holds the title thereby acquired may bring an immediate petition in the superior court for the foreclosure of all rights of redemption thereunder upon a finding by the superior court of a.bandonment. Said petition shall include a description of the lasd to which it applies, with its assessed valuation, the petitioner's source of title, giving reference to the 
- place, book and pare of the record, and such other facts as may be neccssary for the information of tho court. $\Lambda$ finding of abandonment shall bo mado under the following circumstances:

(a) The summons initiating the proceedings for the forcclosure of all rights of redemption and directed to the taxpayer(s) at the taxprayer's promises, or at the last known address of the taxpaycr, if known by the petitioner to be different from that of the taxpayer's premises, is returued noi found.

(b) Ipon the return of such summons as "not found", the petitioner may move the ccurt, notice of the motion having been sent to the taxpayer by certified mail at the taxpayer's last known address, for the appointment of the code enforcement officer of the city or town or other appropriate persoil as an officer of the court to make a personal inquiry into the whereabouts of the taxpayer. Such an inquiry shall include visits to the taxpayer's premises, inquiries with neighbors, known relatives, empioyers, and any other person o. entity whom the officer may reasonably conclude has information to the whereabouts of the taxpayer.

(c) If the officer of the court, upon such inquiry, is unable to ascertain the whereabouts of the taxpayer, the count may, upon hearing the report of the officer and being satisfied as to its thorougliness, enter a finding that the taxpayer's premises are abandoned, and order that all rights of redemption thereunder be immediately foreclosed on account of said abandonmant.

(d) If the inquiry of the officer resuits in the location of the taxpayer, the taxpayer shall be ordered by the couturt to appear for the limited purpose of declaring his intention with regard to exercising lịs right of redemption over the property. If, upon making such an appearance, the taxpayer states that neithor he nor anyone holding under him intends to occupy the mort- 
gaged prenises, the court may order that all rights of rodemption be immediately foreclosed on account of said abnnclomment.

(c) Any person who willeully misreprescnts facts regarding the fiuding of abandomuent of taxpayer's premises or who enginges ju harrassment or pressure to cause taxpnyer's to abandon premises or otherwisc fraudulently olitains a finding of abandoument or a finding that premiscs have not becn abandoncd, shall be guilty of a misdemcanor punishable by a fine of not Icss than $\$ 1,000$ or 30 days in prison.

(f) Actions brought uncter this scction to foreclose the right of redemption on account of abandonment in the superior court shail be given precedence on the calendar and shall we heard no latep than thirty (30) days from the initiation of such proceedings.

Sec. 2. Sections 45-4-4-4 and 45-14-11 of the general laws entilled "Homestead program" are hereby amended to jead as follows:

45-44-4. CONDITIONS REQUTRTD BY APPISCANIC.-Homestead program property will be offered to qualified applicants at no initial cost on a conditional deed basis provided that the applicant:

* *

(d) Lives in, copies, and maintains as a single, two, or three fanily dwelling to city or town housing standards the parecl assigned to him for a period of not less than three (3) year's.

45-44-11. RFSPONSIBILITIES ANJ) DUTIFS OF BOARD.-The board is cupowered and has the duty and responsibility to:

(6) Accept any real property donated to the city or town which qualifies or is eligible for rehabilitation under the homestead program.

Sec. 3. This act shall talie effect upon its passage. 


\section{EISPLANATION}

This act would allow a city or town or an individual to bring a petition in the sujerior court to forecioso the right of redemplion immorliately following in lax sale upou a finding of abandomment. 'This act would also make two and threo fanily dwellings eligible for the homestead prowram and allow the homestead board to accept property donated to the city for rehabilitation.

This act would take effect upon passage. 
APPENDIX III.

PRIVATE REDEVELOPHENT LEGISLATION

\section{EXPLANATION}

This act would provide incentives for the privalte sector to become involved in projects normally undertaken by redevelopment agencies. $\Lambda$ forty year exemption from state and local taxes would be granted to developers undertaking projects in redevelopment areas and approval by the city or town as well as the state. Payments in lieu of taxes would be required over this forty year period. These payments would be geared to income and would have to equal at leasit as much as the eity or town received from the property prior to redevelopment. Corporation's undertaking such projects would be limited to an 8 percent profit. Any profit over and above this figure would have to be paid to the city or town. The key incentives, therefore, are tax stabilization and payments in lieu of taxes based on revenue. Only projects deemed to be in the public interest would be eligible for these benefits. 
(b) "Department" means the department of community affairs, acting in consultation with the departments of administration and economic development.

(c) "Local agency" means a redevelopment agency created jursuant to chapter 45-31 of the general lars, or where no such redevelopment agency exists, a municipal agency designated by the governing body of the community to administer the provisions of this chapter.

(d) "Project" means any undertaking consisting of the construction in a redevelopment area of decent, safe, and sanitary residental, commercial, industrial, institutional, recreational, or governmental buildings and such appurtenant or incidental facilities as shall be in the public interest, and the operation and maintenance of such buildings and facilities after construction. A "project" may include as incidental thereto any ore or more of the following:

(i) acquisition and assembly of the land (and buildings and structures and other improvements thereon, if any) within a redevelopment area;

(ii) clearance of the land within a redevelopment area;

(iii) acquisition, assembly, and clearance of land, builingrs, or structures not in themselves blighted and substandard if their inclusion is necessary for the clearance, redevelopment, reconstmation, or rehabili. tation of a redevelopment area; and

(iv) installation, construction, and reconstruction of public and private ways, public utilities and se:vices, and site improvements essential to the preparation of a redevelopment area for beneicial develop. rent or redevelopment.

(e) "Urban redevelorment corporation" or "corpomtisn" monns a nrivate corporation established pur- approved pursuant to the provisions of this chapter.

(f) "Zoning ordinance or by-law" means any special statute establishing zoning regulations, in one or more cities, towns, or districts, or any ordinance or by-law adopted under chapter $45-24$ of the Rhode Island general laws.

45-32.2-2. DECLARATION OF PUBLIC NECESSITY; ACQUISITIGN AND REGULATIONG OF PRIVATE PROPERTY.-It is herepy declared that blighted and substandard areas exist in certain cities and towns in this state, and that each of such areas constitutes a serious and growing menace, injurious and inimical to the safety, health, morals, and welfare of the residents of the state and the sound growth of the communities therein; that the existence of each of such areas contributes substantially to the spread of disease and crime, necessitating excessive and disproportionate expenditure of public funds for the preservation of the public bealth and safety, for crime prevention, correction, prosecution, punishment, and the treatment of juvenile delinquency and for the maintenance of adequate police, fire, and accident protection and other public services and facilities, constitutes an economic and social liability, substantially impairs or arrests the sound growth of cities and towns, and retards the provision of residential, commercial and industrial buildings and other improvements; that each of such areas decreases the value of private investments and threatens the sources of public revenue and the financial stability of com. munities; that because of the economic and social interdependence of different communities and of different areas within single communities the redevelopment of land in blighted and substandard areas in accordance with a comprehensive nlon to du 
to achieve permanent and comprehensive elimination of existing slums and substandard and blighted conditions and to prevent the recurrence of such slums or substandard and blighted conditions or their development in other parts of the community or in other communities; and that the redevelopment of blighted and substandard areas promotes the clearance of substandard and blighted areas and prevents their creation and occurrence; that the menace of blighted and substandard areas is beyond remedy and control solely by regulatory process in the exercise of the police power and cannot be deait with effectively by ordithary operations of private enterprise without the aids berein provided; that the developinent of property for the purpose of eliminating biighted and substandard conditions thereon and preventing recurrence of such conditions in the area, the removal of structures and improvement of sites, and disposition of the property for redevelopment incidental to the foregoing, the exercise of powers by housing or redevelopment agrencies and any assistance which may be given by cities and towns or any other public bodies in con. nection therewith, are public uses and purposes for which the aids herein provided may be given, public woney expended, and the power of eminent domain exercised; that a public exigency exists which makes the use, acquisition, planning, clearance, rehabilitation, or rebuilding of such blighted and substandard areas for residential, commercial, industrial, institutional, recreational, or governmental buildings and appurtenant or incidental facilities as herein provided à public use and benefit for which private property may be acquired by eminent domain or regulated by irholesome and reasonable orders, law and directions; and the necessity in the public interest for the a matter of legislative determination.

It is hereby further declared that in many areas throughout the state there is a shortage of decent, safe, and sanitary buildings for residential, commercial, industrial, institutional, recreational, or governlilental purposes; that this condition is most extreme in communities where blighted and substandard areas exist; that the aforisaid conditions cannot be corrected by the ordinary operations of private enterprise without the aids herein provided; that the provisions of this statute will stimulate the investment of private capital in blighted and substandard areas, and in the construction, maintenance, and operation in such areas of needed decent, safe and sanitary residential, commercial, industrial, institutional, and recreational buildings; that the construction, maintenance, and operation of such buildings on such land in such areas will assist in achieving permanent and comprehensive elimination of existing slums, and sub. standard and blighted conditions and in preventing the recurrence or redevelopment of such conditions.

45-32.2-3. ESTABLISHIIENT OF CORPOEATIONS TO CARPY OUT PROJECTS; NUTRER OF PROJECTS FOR EACH CORPORATION; CO-OPERATIVE CORPORATIOINS. - Three or more persons may associate themselves by written agreement of association in a form furnished or approved by the secretary of state with intent to form a corporztion for the purpose of undertaking and carrying out in any city or town a project authorized and approved by the local agency and by the department. No such corporation shall undertake more than one project or engage in any other type of activity.

A nonbusiness corporation organized under chapter 7-6 of the Rhode Island general laws, the property 
the benefit of any private person or entity, and which is approved by the local agency, is hereby empowered to act as an urban redevelopment corporation pursuant to all other provisions of this chapter, except as hereinafter provided, for the purpose of rehabilitating ard improving residential housing. Such a corporation may sell any redevelopment project within a forty sear period, provided that any profits shall be employed in further redevelopment projects. Such a corporation shall be exempt from the provisions of section eleven, provided that surplus earning profits from such projects, however categorized, shall be employed in further urban redevelopment projects.

The laws relative to corporations organized under and subject to chapter 7-1.1 of the Rhode Island general laws as far as cousistent with the provisions of this chapter and rules and regulations made under authority thereof, shall apply to corporations so formed and such corporations are hereby declared to be instrumentalities of the state.

45-32.2-4. RUIES AND REGUIATIONS; STAR. DARDS FOR PROJECT PLANS; VARIATIONS. Local agencies may make, and from time to time amend, reasonable rules and regulations in regard to the procedure for securing the approval of projects uncier this chapter and for the financing, construction, management, and maintenance of such projects. The department shall, for the guidance of the proponents cf a project, fix general standards to winich the plans of such project shall conform. Variations from such stancards may be allowed for the accomplishment of the purposes of this chapter. Such standards may contain provisions more restrictive than those im. posed by applicable planning, zoning, health, and builking laws, ordinances, by-laws, and regulations.
PROJECT; CONTENTS.-The persons who have executed an agreement of association under section three with intent to form a corporation for the purpose of underteking and carrying out a project in any city or town shall, before presenting the agreement of association to the state secretary for filing, submit to the local agency and to the department an apllication for their approval of the project for the carrying out of which the corporation is sought to be formed and their consent to the formation of such corporation. Such application shall specify the location of the proposed project and shall state the raasons why the project is necessary or desirable, the uses to which the project is to be put, the estimated cost of the project, and the amount of capital which it is intended to raise. Such application shall also contain in general terms a description of the buildings, structures or facilities which it is proposed to furnish, and shall be accompanied by a site plan and typical building plan and typical elevations of the proposed buildings or structures.

45-32.2-6. REPORT BY LOCAL AGETCY ON APPLICATION TO FORII CORPORATION; REPORT OF LOCAL AGEYCY; DISPOSITION BY LOCAL AGFNCY. - Whenever the local ageney is asked to approve the formation of a corporation inder section three, it shall transmit the application to the mayor of the city or the councilmen of the town in which the proposed project is to be located, and the mayor or the councilmen, as the case may be, shall request the local agency of such city or town to make a report on such application.

The planning commission shall determine whether or not the proposed project conflicts with the comprehonsive community plan of the city or town and 
trimental to the best interest of the public or the city or town or to the public safety and convenience, or inconsisient with the most suitable development of the city or town, and whether or not the project will constitute a public use and benefit.

If the carrying out of a project will involve the destruction or rehabilitation of buildings occupied in whole or in part as dwellings, the local agency shall determine whether or not there is a feasible method for the temporary relocation of families displaced from the project area and whether or not there are, or are being provided, in the project area or in other areas not generally less desirable in regard to pub. lic utilities and public and commercial facilities and at rents or prices within the financial means of the families displaced from the project area, decent, safe, and samitary dwellings equal in number to the number of, and available to such displaced families and reasonably accessivle to their places of employment. Unless it finds that there is such a feasible method and that such dwellings exist or are being provided it shall not approve the project. Any relocation paywents wade undor this section, shall be in accordance with the provisions of sections 45-31-26 and 45-3127 of the general laws.

The local agency shall submit to the mayor or the councilmen a report which shall be open to public inspection, approving or disapproving the project, together with its reasons for approval or disapproval. The major or the councilmen shall transmit the report of the local agency to the department together with his or their approval or disapproval of the project.

The department, if it receives a certificate evidencing the approval of the mayor or the councilmen, ditions exist which warrant the carrying out of the project and that in its opinion the cost of the project has been correctly estimated and the project will be practicable, and that the construction and use of the project will not be in contravention of any zoning, subdivision, health, or building ordinances or by-laws or rules and regulations of the city or town, in effect in the location of the proposed project, or of any of the staudards established pursuant to section 4 of this chapter, shail issue a certificate that it approves the project and consents to the formation of a corporation to carry it out. The agreement of association shall not be presented to the state secretary for filing, nor shall he file it, unless it is accompanied by such certificate. If the department disapproves the project, it shall state its objections in writing and may suggest changes in the project, or in the plans therefor, which if adopted, would meet its objections. If the persons so associated determine to proceed in accordance with the modifications suggested, they shall amend their application accordingly and submit the application as amended to the department for its approval. The department may approve or disapprove such application as amended, unless in its opinion the proposed modification is a fundamental one. In such case the department shall transmit the application as amended to the local agency and to the mayor of the city or the councilmen of the town in which the project is to be located, and the provisions of this section in respect to original applications shall be applicable thereto.

Whenever the department finds that the construction or use of a proposed project would be in contravention of any zoning, subdivision, health, or building ordinances or by-laws or rules and regulations 
proposed project, and the application filed under section five proposes any waiver, variance, or amend. ment of such ordinances, by-laws, rules, or regulations, which if granted or effected would make the proposed project in conformity therewith, the department may issue a certificate that it consents to the formation of the corporation subject to such conditions as may be set forth in such certificate with respect to the obtaining of such waiver, variance, or amendment. Whenever any such conditional certificate shall be issued by the department, the agreement of association may be presented to the state secretary for filing, ond he shall file it, and the corporation shall then be for all purposes a corporation organized under this chapter; provided, however, that the corporation shall not enter upon the construction of a project or portion thereof until the department shall have issued a certificate to the effect that the corporation has complied with all of the conditions set forth in such conditional certificate which relate to the project, or the portion thereof proposed to be pirced under construction.

45-32.2-7. CONTRACTS; CONTMNTS. - As soon as any such corporation determines to carry out a Froject approved by the department, such corporation and the city or town in which its project has been authorized shall contract for the carrying out of such project, in accordance with the application, the provisions of this chapter, and the rules, regulations, and standards prescribed by the local agency and/or the department for such project. Such contract may provide that, without mutual consent, any subsequent amendinent of ary such provisions, mles, regulations, and standards shall not affect the project. Wothing in this section shall prevent such contract from further providing for such corporation to pay to the city cific or ascertainable amount in addition to the excise prescribed by seciion twelve as may have been stated in the application.

45-32.2-8. BOREOWING MONEY TO FINANCE PROJECT; CAPITAL STOCK SUBSCRIPTIONS AND SALE; STOCIS, BOINDS, OR OTHER SECURITIES OF CORPORATION AS LEGAL INVESTMENTS.-No more tian such proportion of the estimated cost of a project, not exceeding ninety percent thereof, as the local agency and/or the department will approve, shall be raised by borrowing the same, and the remainder of such estimated cost and such additional capital as the department and/or the local agency has required or approved, unless provided by grants or gifts, shall be raised by subscription to or sale of the capital stock of the corporation. Only stock having par value shall be issued by such a corporation, except as the department shall approve the issue of stock without par value and the consideration to be paid therefor. No such corporation shall, without the approval of the local agency and/or the department, enter upon the construction of a project until the full amount to be paid for its capital stock as above determincd has been received by the corporation in cash or in property or, with the approval of the local agency and/or the department, in serv. ices or materials or contracts for services or materiais. So long as funds made available by the federal government or any instrumentality thereof or any mortgage or mortgage bonds insured or guaranteed by the federal housing commissioner or the administrator of veterans' affairs or any other instrumentality of the federal government are used in financing, in whole or in part, any project under this chapter, such corporation mav borrow such amownt ahnva ninatr 
approved by the local agency and/or the department, notwithstanding the foregoing limitation on borrow. ing. Any such corporation may issue such stock as may be required by any federal agency, instrumentality or officer as a condition to loans secured by mortgages insured or guaranteed by the federal governLent or any agency or instrumentality thereof. The stock of such a corporation shall first be offered to the owners of the real estate within the location of the project and each owner may subscribe to said stock in an amount not in excess of the value less encumbrances of his real estate within such location and may pay his subscription by a deed of his said real estate, to be held in escrow by the department and/ or the local agency until the full amount of the capital has been raised. The valuation of said real estate for the purnoses of this section shall be determined by arreement, subject to the approval of the local arency and / or the department, and if the parties cannot agree upon the valuation, it shall be determined by the local agency and/or the department. If the owner is dissatisfied with the amount so offered, his deed siall be returned to him and his subscription shil be cancellec, but his right to subscribe to the stock in cash if he so elects and his right to recover the value of his land in the appropriate proceedings if taken by eminent domain shall not be impaired by his action under this section.

So much of the stock as has not been subscribed for by the owners of the real estate within thirty cays aiter it has been offered to them shall be issued to the persons who signed the agreement of associat:on, in proportion to but not in excess of their respective subscriptions and any remaining stock shall poration shall, subject to the approval of the insurance commissioner be legal investments for the capital and other funds of insurance companies, and the bonds and notes of such a corporation, when secured by a first mortgage upon its real estate shall, sub. ject to the approval of the banking commissioner, be legal investments for the deposits and the income derived therefrom of financial institutions governed by title 19 of the general laws.

45-32.2-9. PURCHASF OR IEASE OF REAL ES. TATE BY URBAN RFDEVELOPMENT CORPORA. TION FROM LOCAL AGENCY; APPROVAL. - A corporation organized under section three or an insurance company or a group of insurance companies or a financial institution or group of financial institutions governed under title 19 of the general laws operating under this chapter may purchase or lease from a housing authority, redevelopment agency, municipality, or other public body real estate acquired by such authority, municipality or public body for land assembly and redevelopment or urban renewal purposes or redevelopment purposes under chapter 45-32 of the general laws upon such terms and conditions, consistent with this chapter, as shall be approved by the local agency and may erect and maintain a project upon the land so acquired. Such corporation shall not be required to offer its stock to the owners of the real estate within the location of the project and such owners have no preferential right to subscribe thereto; but in all other respects the provisions of this chapter shall be applicable to corporations acting thereunder and their projects.

45-32.2-10. PROCEEDINGS UPON VIOLATION OF RULTS AND REGULATIONS WITE RESPECT 
violated any of the provisions of this chapter or the requirements thereunder with respect to the financing of a project, or to the paymerts therefor, or that the rules and regulations applicable to a project have not been complied with, or that a project is not maintained in such a way as to carry out the purpose for which it was desinned, it shall notify the holders of any mortgages, or mortgage bonds thereon, or the trustee, if any, for the bondholders, and it may institute a proceeding in equity in its own name for the purpose of preventing, or requiring, as the case may be, by injunction or otherwise, any such act or failure or omission to act. The remedies provided in this section shall be in addition to and not in submission for any other available reinedies.

45-32.2-11. LIMITATION IN REPAYMTNT OF IIVVTSTINTT IN STOCK; LIMITATIONS OF DIVIDENDS. - Except as provided in section eighteen, the stockholders of every such corporation shall be deemed, when they subscribe to and receive the stock thereof, to have agreed that they shall at no tirue receive or accept from the corporation, in repayment of their investment in its stock, any sums in excess of the par value, if any, of the stock, together with cumulative dividends thereon at the rate of eight percent per annum, or in the case of stock without par value, cumulative dividends at the rate of eight percent per annum of the consideration paid for such stock, as determined by the local agency and /or the department at the tiue it approves the issue of such stock. No stockholder in any such corporation shall receive any dividend in any one year in excess of the aforesaid rates, except that when in any prior year or years dividends in the amount althorized to be waid bv such corporation shall not holders shall be entitled to receive the pajment of so much of such deficiency without interest, out of any earned surplus which may be available in any succeeding year, as the board of directors of the corrsoration shall determine. Nothing in this section shall be applicable to the payment of dividends out of profits from the sale of capital assets of the corpora tion. This section shall not apply to nonbusiness corporations organized pursuant to and meeting the standards of section three, provided that all surplus earnings from projects there speciffed, however categorized, shall be employed in further urban redevelopment projects.

45-32.2-12. EXRMPTION FROM TAXATION, BETTARITENTS AID SPECIAL ASSESSIIENTS; CERTIFICATION OF FAIR CASH VALUE; ANNUAL PAYMENTS; DEVELOPNTINT OF PROJ. ECT IN STAGES; RFAL ESTATE LEASED FPOBI PERSONS OTHER THAN A HOUSING AUTHORITY.-For a period of forty years after the organization of any such corporation, such corporation and all its real and personal property, including all real and personal property leased by it from a housing authority or from a redevelopment agency or from a city or town or a corporation wholly owned or controlled by a city or town, shall be exempt from taration and from betterments and special assessments; and for such period any such corporation shall not be required to pay any tax, excise or assessment to or for the state or any of its political subdivision; prorided, however, that notwithstanding the foregoing provisicns of this section, any such corporation shall be required to pay the excises and sums respectively prescribed by this section and section seventeen, provided, further, that nothing in this section shall be 
ters into a contract under section sixteen from agreeing therein to make, or from making pursuant thereto, payments in lieu of betterments, taxes, or special assessments.

Notwithstanding the foregoing provisions of this section, the assessors of every city or town in which real or tangible personal property exempted by this section from taxation shall, on or before June 30th ir such year, deteraine and certify to the stare tax division and to the corporation organized under this chapter which owns or leases such property the fair cash value of such property as of December 31st in such year. On or before the thirtieth day of July then next ensuing, or within thiriy lays after the receipt of the certification of valuation from the assessors, whichever is later, such corporation, if aggrieved by such valuation, may appeal therefrom to the aivision of taxation. Said division shall hear and decide the subject matter of such appeal and give notice of its decision to the assessors and the corporation; and, except as provided in the administrative procedures act such dccision shall be final and conclusive.

During the period of forty yeais after the organization of a corporation under this chapter, such corporation shall pay in each calendar year to the city or town with respect to its corporate existence at any time within the preceding calendar year an excise equal to the sum of the following: an amount equal to five percent of its gross income in such preceding calendar jear, from all sources; and an amount equal to ten dollars per thousand upon the valuation determined as hereinbefore provided to bo the fair cash vaiue as of Jaruary first in tho year in which the excise becomes payable of all real and tangible personal property of such corporation, including all real and empted by this section from taxation; provided, that the excise payable in any year shall not be less than the amount which the city or town would receive for taxes, at the rate for such year, upon whichever of the following valuations is the lesser:

(a): the valuation upon which the aforesaid amount equal to ten dollars per thousand is computed; or

(b) the average of the assessed valuations of the land and all buildings and other things erected thereon or affixed thereto on the three assessment dates, in the case of land purchased, taken or leased by such corporation from a housing authority, redevelopment agency, city, town, or corporation wholly corned or controlled by a city or town, next preceding the acquisition of the land by such housing authority, redevelopment agency, city, town, or wholly owned or controlled corporation, and in the case of ail other land purchased, takan or leased by a corvoration organized under this chapter, next preceding the acquisition thereof by such corporation, the assessed valuation for each assessment date being reduced by all abatements, if any.

Any plan for a project may provide that the project may be developed in separate stages, and such stages may be varied from time to time with the approval of the local agency and/or the department. Whenever a project shall be develcped in stages, any excise payable with respect to cornorate existence in a calendar year ending before construction of the last stage of the project is completed, shall be computed as though each stage constituted a separate project cwned by a separate corporation.

All provisions of the general laws relative to the assessment, collection, payment, abatement, verification, and administration of taxes, including penal- 
be applicable to the excise payable under this section. Said excise shall be paid to the city or town where the project of the corporation is located.

Real estate acquired by a corporation organized under this chapter by lease from any person other than a housing authority, redevelopment agency, city, town, or corporation wholly owned or controlled by a city or town, shall be subject to taxation in the same manner and to the same extent as if such real estate Fere wholly owned and occupied by a private person; but so long as the period of forty years from the crganization of such corporation has not expired and the leasehold estate continues to be held by such corporation, all buildings and other things erected by such corporation on, or affixed by such corporation to, any land acquired by such corporation by such lease sinall, for the purposes of this chapter be deemed to be tangible personal property of such corporation. Real estate acquired by lease as aforesaid shall be excluded in maxing determinations and computing the excise under this section, except that the assessed valnation of all buildings and other things erected thereon or affixed thereto on the three assessment dates rext preceding acquisition by such lease shall be included in computing the average valuation under clause (b) of the third paragraph of this section.

Notwithstanding any other provisions of this chapter or of any other law, the asseszors of the city or town in which a project is to be located may, and upon the request of the department they shall, determine for the purposes of this section the maximum fair cash valie of any proposed project or of any stage or stages thereof. Such determination may be made prior to tine construction of the project or of any stage or stares thereof on the basis of the plan for such mination shall have been made, the fair cash value of the real estate and tangible personal property of the corporation shall in no event be valued for the purposes of this section in an amount exceeding such maximum fair cash value, except upon a showing that the corporation has acquired real estate or tangible personal property not included in the plan upon which such maximum fair cash value was based, and in such event any such excess valuation shall be limited to the value of such additional real estate and tangible personal property.

45-32.2-13. SALE OF LAND AND BUILDINGS; APPROVAL.-Any such corporation shall have power, with the approval of the local agency and/or the department to sell the whole or any part of the land acquired by it under this chapter with the buildings or other structures thereon to another corporation, but such land, buildings, or other structures may be sold only subject to the requirement that any change in the benefits and restrictions applicable to such other corporation and any other changes in the project shall not be valid unless approved in the manner provided in section six.

45-32.2-14. RECEIPT OF LOANS AND GPANTS FROTI THE FFDERAT GOVERAIIENT AND OTIIR SOURCES; BORROWING MONEY; ISSU. ANCP OF NOTES OF INDEBTEDNESS.-Any such corporation shall have power to receive loans and grants from the federal government or any agency or instrumentality thereof or from any other source, public or private, or to act as agent of or to co-operate with the federal government or any agency or instrumentality. thereof on any project of the bind or character authorized by section three; provided that nothing in this section chall nnorsto to imnoin tha 
partment with respect to any such corporation or any project operated by it. Any such corporation shall also have power, subject to the provisicns of section eight, to borrow money and to issue bonds, notes, and other evidences of indebtedness and to secure the same by the mortgage of its property or the pledge of its revenues, and to do whatever is necessary or convenient to carry out and effectuate the provisions of this chapter.

Notwithstanding any other provisions of this chapter, any such corporation may borrow on mortgages insured or guaranteed by the federal government or any agency or instrumentality thereof to the extent permitted by the federal government or such agency or instrumentality, and may issue such stock, enter into such agreements or perform such acts as may be required by the federal government or its agency or instrumentality in connection with such insurance or guarantee.

45.32.2-15. APPLICATION TO MODIFY TYPE AND CHARACTER OF BUILDINGS CN PROJECT; APPROVAL. - Any such corporation may apply to the local agency for leave to modify the type and character of the buildings on a project. The local agency may atprove such application, unless in its cpinion the proposed modification is a fundamental one, in which case the provisions of section five and secion six shall apply to an application for such modificaticn.

55-32.2-10. CONTRACTS WITH CTTISS OR TOWIS PELATIVE TO PUBLIC AND PRIVATE WAYS, SIDEWALKS, PARKS, AND OTFER PUBIIC IIIPROVENTNTS; CONTRACTS FOR SALE, LEAST, OR EXCHAKCE OF REAL ESTATE.-Any such corporation may enter into a coniract with the or with the appropriate board or officer of such city or town, and any such city or town or such board or officer may enter into a contract with such a corporation, by which such city, town, board, or officer obligates itself or liimself, subject to applicable law or local ordinances, to do any or all of the following things:

(a) lay out and construct, alter, relocate, change the grade of, make specific repairs upon or discontinue, public ways and construct sidewallss, adjacent to or through a project, if such action is found to be required by the common necessity and convenience;

(b) cause parks, playgrounds or schools, or water, sewer, or drainage facilities, or any other public improvements which it is otherwise authorized to undertake, to be laid out, constructed or furnished adjacent to or in connection with a project;

(c) cause private ways, sidewalks, footpaths, ways for vehicular travel, playgrounds, or water, sewer or drainage facilities and similar improvements, to be constructed or furnished within the site of a project for the particular use of a project or of those dwelling therein.

If any city or town or a local agency acting under any provision of law has acquired or is about to acquire real estate by purchase or eminent domain for purposes of urban redevelopment or similar purposes, such city or town, or such local agency, may enter into a contract with a corporation organized under section three for the purchase, sale, lease, or exchange of real estate held by either of the parties to such contract, in order to more effectively carry out the provisions of this chapter.

A contract under this section between a city or town or a local agency and a corporation organized 
rision of law relating to publication or to advertising for bids.

40.32.2-17. A.PPLICATION OF RECEIPTS IN EXCESS OF AUTHCRIZTD EXPENDITURES. Should the gross receipts of any such corporation from the operation of a project undertaken by it under authority of this chapter, in any year exceed

(1) operating and maintenance expenses together with such reserves as are necessary to create a fund to replace furnishings and worn-out equipment, including any ground rents or other payments under any lease.

(2) taxes and fees,

(3) interest on mortgages and other indebtedness,

(4) premiums, fees, or other charges or expenses incurred in connection with the insurance or guaranty of any mortgage or the insurance or guaranty of any annual return from a project, including any amounts pasable to the federal housing administration or any other agency or instrumentality of the United States for such purposes,

(5) amortization, in accordance with the provisions of any schedule, plan, or method of amortization described in any application submitted to the department under section five of this chapter, or in any schedule, plan, or method of amortization subsequently submitted to and approved by the local agency and/ or the deproment,

(6) dividends,

(7) authorized transfers to surplus or reserves, and

(8) other payments authorized or approved by the local agency and/or the department, the corporation shall pay to the city or town in which the project is located, the amount remaining if any, by wlich the taxes would have been assessed upon the real estate such year if such real estate and tangible personal property had not been exempt from taxation, exceeded the excise paid by such corporation and distributed to such city or town in such year under section twelve.

The balance, if any, may, subject to the approval of the local agency and/or the department, be applied in whole or in part to reducing the indebtedness of such corporation, to renovating or to improving the property, as by installing additional facilities for tie use of tenants, to the acquisition and development of additional property which shall be subject to the same control and regulation as the original project.

The charges for operation and mainienance may include insurance and reserves essential to the management of the property or necessary to mett requirements for depreciation and amortization of bonded indebtedness, but the amount set aside therefor shall be subject to the approval of the department. Nothing in this chapter shall be construed to obligate the state, or to pledge its credit, to any payment whatsoever to any such corporation cr to any stockholder, bondholder, or creclitor thereof.

45-32.2-18. RIGETS; PPIVILEGES, OBIIGATIONS, AND DUTIES OF CORPORATION AFTER FORTY YEARS OF ORGANIZATION. - Notwith. standing any other provisions of this chapter, if a corporation organized under section three has carried out its obligations and performed its duties as imposed by this chapter for forty years from the date of its organization to the satisfaction of the local agency and the department, as evidenced by a certificate transmitted by the department to the secretary of state, it shall thereafter have all of the rights and privileges of a corporation organized under or sub. 
and be subject to all of the obligations and duties of such a corporation, and such corporation and its stockholders shall thereafter be iree from all of the special limitations, restrictions, obligations, and duties imposed upon corporations organized under section three and the stockholders thereof.

45-32.2-19. SUCCESSOR IN INTEREST TO CORYORATION; OPTIONS; FILING OF CERTIFICAIE.-If an action is brought or if proceedings are undertaken for the foreclosure of a mortgage or lien upon a project or upon any severable portion thereof, or for the termination of the corporation's leaselold or other interest in the same, or if in order to avert such action or such proceedings the corporation shall make a conveyance or otherwise release or quitclaim its interests in the same, the successor in interest thereto, including the federal government or any instrumentality thereof, shall, upon its acquisition of the project or severable portion thereof, have the option of

(1) holding the same subject to all the provisions of this chapter and having all of the powers, rights, privileges, benefits, and exemptions set forth in this chapter; or

(2) conveying or otherwise releasing its interest to a purchaser who agrees as part of the terms of convefance or release to hold the same subject to all of the provisions of this chapter and who shall thereby have all of the powers, rights, privileges, benefits and exemptions set forth in this chapter; or

(3) in the case of organization subject to the supervision of the insurance or the banking commissioner, with the prior written approval of the commissioner exercising supervision, and in the case of n cornorntion ormanized under this chapter or any proval of the local agency and/or the department,

(a) holding the project or severable portion thereoi so acquired free from all restrictions and limitations imposed by this chapter and without any of the powers, rights, privileges, benefits, and exemptions thereby conferred, or

(b) conveying or otherwise raleasing its interest in the project or a severable portion thereof to a purchaser to be held by such purchaser free of all restrictions and limitations imposed by this chapter, and without any of the powers, rights, privileges, benefits, and exemptions thereby conferred; provided, however, that whenever any successor in interest or purchaser therefrom holds the project or severabio portion thereof subject to all the provisions of this chapter and having all the rights, powers, privileges, benefits, and exemptions set forth in the chapter, the periods of forty years set forth in sections trelve and eighteen of this chapter shall be computed from the date of organization of the corporation which initiated the project, regardless of any default upon the part of such corporation.

Whenever any such successor in interest or purchaser therefrom shall exercise any option under this section it shall file with the local agency and the department or with the commissioner exercising supervision, as the case may be such cerificates as may he required by the local agency and the depariment or the commissioner. Any such option may be exeicised at any time within one year from the date of acquisition of interest and until such certificate shall have keen filed the project or portion thereof shall be held subject to all of the provisions of this chapter and the successor in interest shall have all the powers, rights, privileges, benefits, and exemptions there- 
45-32.2-20. AUTHORITY OF INSURANCE COMPANIES TO UNDERTAKE PROJECTS; EXCEP. TIONS.-An insurance company incorporated under the laws of the state or authorized to transact business in the state, instead of investing its funds in the stocks, bonds, and other securities of a corporation organized under section three, may with the approval of the commissioner of insurance itself undertake on land owned or to be acquired by it, one or more projects under this chapter, and the provisions of this chapter specifically including the powers granted by sections seven and thirteen, shall so far as apt, be apyicable to such company and such projects, excepting the following:

(a) Section three shall not be applicable to such company, but if an insurance company undertakes more than one project, the accounts for each project shall be kept separately, and the income of one project shall not be exponded upon or for the benefit of arother project.

(b) The application for the approval of a project, siall be submitted by the directors of the insurance company and an application so submitted shall be subject to all of the provisions of this chapter relative to applications by the persons who have executed an agreement of association.

(c) So much of section six as relates to the agreemert of association shall not be applicable to such company.

(d) Section eight shall not be applicable to such company.

(e) Section eleven shall not be applicable to such company; but such company shall not receive or accept for its general purposes as net income from a in which it owns or has owned the project, except that, if in any year it has so received a sum less than the aforesaid eight percent, it may so receive in a subsequent year or years additional sums not exceeding in the aggregate such deficiency without inter. est. Nothing in this section shall be applicable to the payment of dividends out of profits from the sale of the capital assets of the corporation.

(f) So much of section twelve as applied to the taxation of a corporation organized under section three shall apply to an insurance company only with respect to a particular project or to particular projects, and such company shall remain subject to all other taxation imposed by law with respect to its othe: activities and property. If an insurance company occupies or uses one or more parts of a project for puryoses of its business not directly related to the construction, alteration, maintenance, repair, operation, or management of such project, the gross income from such business shall not be included in computing its gross income from all sources but in lieu thereof such amount as the insurance company and the local agency shall in each year not later than September thiritein agree, or in the event of their failure to so agree, the commissioner of insurance shall determine, to be the fair rental value for such year of the floor area so occupied or used shall be included in computing gross income from all sources.

(g) So much oî section seventeen as relates to reducing the indebtedness of a corporation shall apply to indebtedness incurred in connection with a project.

(h) So much of section eighteen as provides that under certain circumstances a corporation shall have all of the rights and privileges of a corporation or- 
land general laws shall be construed to mean that an insurance company may under like circumstances lawfully continue to hold the project but shall in other respects be subject to all of the obligations and duties of an insurance company.

(i) The period of forty years set forth in sections twelve, eighteen, and nineteen shall be computed for a particular project from the date of approval of such project.

The words "insurance company" or "such company" as used in this section shall be deemed to include a group of insurarce companies.

45-32.2-21. AUTIORITY OF FINANCIAL INSTITUTIONS TO UNDTRTAKE PROJPCTS; LINIITATIONS.-A financial institution governed by title 19 of the general laws subject to such regulations as the banking commissioner deems necessary or aảvisabie, may, either alone or in conjuction with one or more other financial institutions undertake one or more projects under this chapter. The provisions of section twenty shall, so far as apt, be applicable to such financial institution or institutions, except that the board of investments of a financial institution shall have the powers and duties granted to or imposed upon directors of an insurance company under said section. No investment whall be made by a savings bank under this scction if thereby the total amount invested by such financial institution pursuant to this section would exceed three percent of the deposits of sich savings bank.

45-32.2-22. AUTIORITY OT CORPORATION TO TAKE OVER EXISTIKG PPOJECT; $\triangle P P L I C A-$ TION; CEANGES IN PROJECT; CRRTIIICATE OF BOARD.-Threa or more persons may associate themselves by written agreement of association, in state, with intent to form a corporation for the purpose of acquiring a project which has been authorized and approved and which has been deyeloped or is being developed in accordance with the provisions of this chapter, for the purpose of acquiring any severable portion of such project. The persons who have executed such an agreement of association shall, before presenting the agreement of association to the state secretary for filing, submit to the local agency or department an application for its consent to the formation of such corporation. Such application shall specify the project or portion thereof which it is proposed to acquire, the terms upon which the same is to be acquired, and the amount of capital which it is intended to raise. If it is proposed that any modifications in the project be made, the application shall include such information concerning the proposed modifications as the local agency sacill require. If the local agency determines that the persons who have executed the agreement of association appear to hare the ability requisite to perform the cbligations and carry out the duties imposed by this chapter with respect to the project, and that none of the proposed modifications, if any, in the project are fundamental, the local agency and the department shall issue a certificate that they consent to the formation of the corporation. The agreement of assosiation shall not be presented to the state sacretary for fling, nor shall he file it, unless it is accompanied by such certificate. If any modifications in the project are proposed in the application and if the local arancy determines that any such modifications are fundamental, the application shall be reconsidered purzuant to the procedure set forth in section six, but with such variances as the local agency and/or the depart. 
complishment of the purposes of this section. A cor. poration organized under this section shall have all of the powers, riglits, privileges, benefits, and exemptions and shall be subject to all the duties of a corporation organized under section three; provided, how. ever, that the periods of forty years set forth in sec. tions twelve and eighteen shall be computed from the date of organization of the corporation which initiated the project regardless of any default upon the part of such corporation which initiated such project.

45-32.2-23. AUTEORITY OF INDIVIDUALS TO UNDERTAISE OR ACQUIRE AID CARRY ON URBAN REDEVELOPMENT PROJECTS.-Individuals and associations of individuals in the form of joint ventures, partnerships, limited partnerships or trusts resident or organized in the state, or nonbusiness corporations organized under chapter $7-6$ of the Rhode Island general laws may undertake projects under this chapter or acquire projects from corporations organized under this chipter, which projects shall be exempt from taxation, bettements, excises, and special assessments, provided that such persons or associations, with respect to any such project undertaken or acquired by them, shall:

(a) be subject to rules made pursuant to section four;

(b) make an application for approval of a project containing the same facts required of a corporation by section five;

(c) agree by regulatory anteement entered into with the local agency and/on the department as to financing the cost of the project;

(d) keep accounts for such projects separate from ........ivitine ennaucted by them and shall not ings described in clause (e) upon or for the benefit of any other of their activities;

(e) agree by regulatory agreement entered into with the local agency and/or the department that they will comply with the provisions contained in section ten relative to compliance with the financing program and rules and regulations applicable to a project, and will not receive or accept as net income from a project any sum in excess of eight percent of the amount invested by them in such project for each year in which they own or have owned the project, except that, if in any year they have so received a sum less than the aforesaid eight percent, they may so receive in a subsequent jear or years additional sums not exceeding, in the aggregate, such deficiency without interest. Nothing in this section shall be applicable to the payment of dividends out of profits from sale of the capital assets of the corporation;

(f) agree by regulatory agreement with the lccal agency and/or the department that in consideration of exemption from taxation of real and personal prop. erty and from betterments and special assessments and from the payment of any tax, excise, or assessment to or for the state or any of its political subdivision on account of a project, they will pay the excise with respect to a project which a corporation would be bound to pay under the formulae and prorisions set forth in section twelve and any nonbusiness corporation which enters into such a regulatory agreement shall be deemed to have waived its exemption from local property taxes.

Any such regulatory agreement shall be binding upon the heirs and assigns of the parties thereto.

An application under this section shall be reviewed and disposition thereof made in accordance with the 
except that the provisions relating to an agreement of association shall not apply.

The provisions of section seven, nine, fourteen, fifteen, sixteen, seventeen, and eighteen relative to corporations organized under this chapter shall extend to anyone undertaking or acquiring a project under this section, so far as apt.

If the persons or organizations described in this section have carried out their obligations and performed their duties as inposed by this chapter for a period of forty years from the date of approval of a project to the satisfaction of the local agency and the department as evidenced by a certificate issued by the department, they shall thereafter no longer be subject to the obligations of this chapter nor enjoy the rights and privileges hereby granted.

Every project undertaken or acquired under this section shall be deemed to have been undertaken or acquired to serve a public purpose.

45-32.2-24. SEVERABILITY. - The provisions of this chapter are hereby declared to be severable, and if any such provision, or the application of any such provision to any person or circumstance shall be held to be invalid or unconstitutional, such invalidity or unconstitutionality shall not be construed to affect the valicity or constitutionality of any of the remaining provisions of said chapter or the application of such provision to persons or circumstances other than those to which it is held invalid.

Sec. 2. This act will take effect upon its passage.

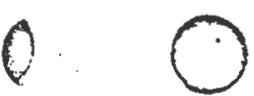

